\title{
Molecular Changes Underlying Hypertrophic Scarring Following Burns Involve Specific Deregulations at All Wound Healing Stages (Inflammation, Proliferation and Maturation)
}

\author{
Matúš Čoma ${ }^{1,2}$, Lucia Fröhlichová ${ }^{3}$, Lukáš Urban ${ }^{1,4}{ }^{\text {, Robert Zajiččk }}{ }^{5}$, Tomáš Urban ${ }^{5}$, Pavol Szabo ${ }^{6,7}$, \\ Štěpán Novák ${ }^{6,8}$, Vitaly Fetissov ${ }^{5}$, Barbora Dvořánková ${ }^{6,7}$, Karel Smetana Jr. $6,7, *$ (D) and Peter Gál $1,4,5, *$ (D) \\ 1 Department of Biomedical Research, East-Slovak Institute of Cardiovascular Diseases, Inc., \\ 04011 Košice, Slovakia; mcoma@vusch.sk (M.Č.); lurban@vusch.sk (L.U.) \\ 2 Department of Pharmacology, Faculty of Medicine, Pavol Jozef Šafárik University, 04011 Košice, Slovakia \\ 3 Department of Pathology, Louise Pasteur University Hospital, 04190 Košice, Slovakia; \\ lucia.frohlichova@unlp.sk \\ 4 Center of Clinical and Preclinical Research MediPark, Pavol Jozef Šafárik University, 04011 Košice, Slovakia \\ 5 Prague Burn Centre, Third Faculty of Medicine, Charles University and University Hospital Královské \\ Vinohrady, 10034 Prague, Czech Republic; robert.zajicek@lf3.cuni.cz (R.Z.); tomas.urban@lf3.cuni.cz (T.U.); \\ vitaly.fetissov@fnkv.cz (V.F.) \\ 6 Institute of Anatomy, First Faculty of Medicine, Charles University, 12800 Prague, Czech Republic; \\ pavol.szabo@lf1.cuni.cz (P.S.); stepan.novak@lf1.cuni.cz (Š.N.); barbora.dvorankova@lf1.cuni.cz (B.D.) \\ BIOCEV, 25250 Vestec, Czech Republic \\ check for \\ updates \\ 8 Department of Otorhinolaryngology, Head and Neck Surgery, First Faculty of Medicine, Charles University \\ and University Hospital Motol, 15006 Prague, Czech Republic \\ * Correspondence: karel.smetana@lf1.cuni.cz (K.S.J.); pgal@vusch.sk (P.G.); Fax: +421-55-789-1613 (P.G.)
}

Citation: Čoma, M.; Fröhlichová, L.; Urban, L.; Zají̌cek, R.; Urban, T.; Szabo, P.; Novák, Š.; Fetissov, V.; Dvořánková, B.; Smetana, K., Jr.; et al. Molecular Changes Underlying Hypertrophic Scarring Following Burns Involve Specific Deregulations at All Wound Healing Stages (Inflammation, Proliferation and Maturation). Int. J. Mol. Sci. 2021, 22, 897. https://doi.org/10.3390/ ijms22020897

Received: 8 January 2021

Accepted: 14 January 2021

Published: 18 January 2021

Publisher's Note: MDPI stays neutral with regard to jurisdictional claims in published maps and institutional affiliations.

Copyright: (c) 2021 by the authors. Licensee MDPI, Basel, Switzerland. This article is an open access article distributed under the terms and conditions of the Creative Commons Attribution (CC BY) license (https:// creativecommons.org/licenses/by/ $4.0 /)$.

\begin{abstract}
Excessive connective tissue accumulation, a hallmark of hypertrophic scaring, results in progressive deterioration of the structure and function of organs. It can also be seen during tumor growth and other fibroproliferative disorders. These processes result from a wide spectrum of cross-talks between mesenchymal, epithelial and inflammatory/immune cells that have not yet been fully understood. In the present review, we aimed to describe the molecular features of fibroblasts and their interactions with immune and epithelial cells and extracellular matrix. We also compared different types of fibroblasts and their roles in skin repair and regeneration following burn injury. In summary, here we briefly review molecular changes underlying hypertrophic scarring following burns throughout all basic wound healing stages, i.e. during inflammation, proliferation and maturation.
\end{abstract}

Keywords: wound healing; skin; burn; pathological scar; cell interaction; stem cell

\section{Introduction}

Each year, over 100 million patients in the developed world form scars as a result of surgery and/or trauma [1]. Hypotrophic, atrophic (e.g., acne scars) and linear normotrophic maturated scars have little to no effect on the patient's quality of life (Figure 1) [2]. However, pruritus, pain and contractures often related to extreme scarring, such as hypertrophic or keloid scarring, dramatically affect the patient's physical and psychological state [3-5]. In particular, hypertrophic and keloid scarring are of the highest clinical relevance in burn treatment and esthetic medicine [1]. Since hypertrophic and keloid scarring belong to the family of fibroproliferative disorders, these scars greatly differ from hypotrophic, atrophic and normotrophic scars in their histological features [6]. Clinical differentiation between hypertrophic and keloid scars is often challenging. Proper identification of the scar type is necessary for appropriate management of scar formation and cosmetic surgery approach [7]. Insight into the complex molecular mechanisms involved in extreme scarring reviewed in this article is the key to understand the complicated pathophysiology of 
excessive scarring and related fibroproliferative disorders. In this review, we focus on fibroblasts, the key cellular component in wound healing. We compare their function in normal and hypertrophic wound healing during chronic inflammation, as well as their production and remodeling of extracellular matrix (ECM).
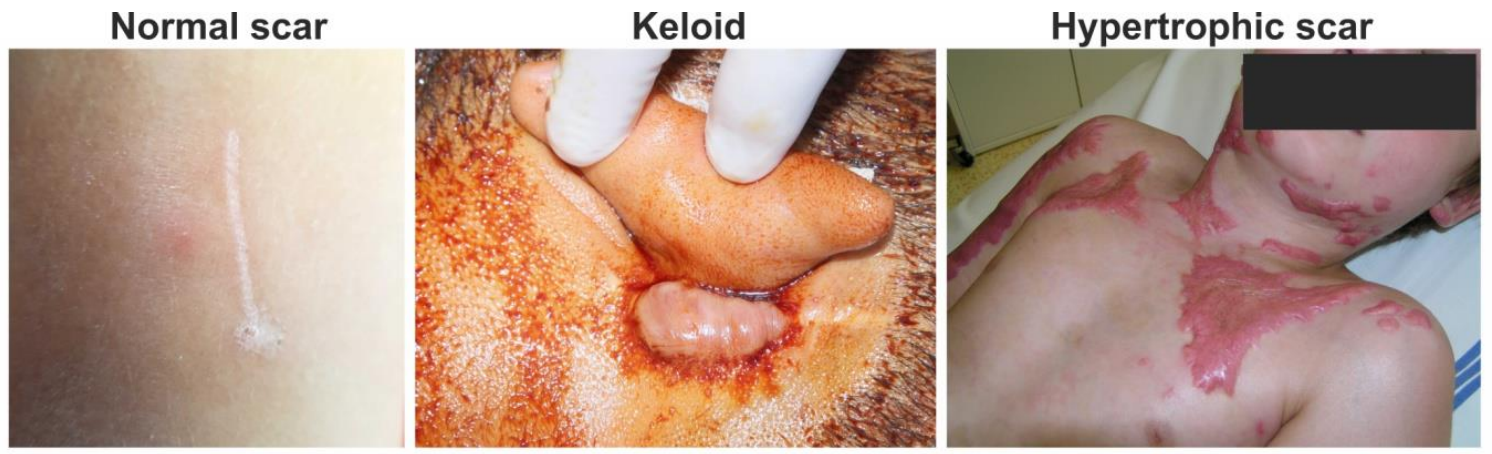

Figure 1. Clinical photos of normal, keloid and hypertrophic scars: normal fine line scar following a surgical wound (left); keloid scar, which extends beyond the original wound (middle); and hypertrophic scar, which does not extend beyond the initial site of the skin lesion associated with burn injury (right).

\section{Inflammatory Phase of Wound Healing}

Wound healing is a very complex process involving activation of different cell types, production of various cytokines, chemokines and many factors affecting immune responses, and is thus prone to errors [8]. Possibly arising imbalances in proinflammatory and antiinflammatory signaling molecules lead to an excessively strong and prolonged inflammatory response causing pathological scarring $[9,10]$. Such scarring was observed following cutaneous injury or/and irritation, including trauma, insect bite, burn injury grade $2 b$, surgery, vaccination, skin piercing, acne, and virus infections. On the other hand, pathological scarring was not observed following superficial injuries not reaching reticular dermis (Figure 2), suggesting a critical role of deeply localized inflammation [11]. Even though inflammatory responses begin immediately after injury, keloid and hypertrophic scars may form weeks or even years after injury [12]. By this time, the wound is closed and the epidermis fully regenerated. The pathological scar therefore results as a product of chronic inflammation of reticular dermis and continuous aberrant dermal matrix production $[11,13]$. During the chronic phase, inflammation of reticular dermis and subsequent scarring can be further accelerated by recurrent trauma or mechanical damage to the dermis layer [14-16]. In general, long and systemic inflammation persistency is typical of burn injuries, particularly in injured patients with severe skin loss and/or deep skin defects [17].

It has been generally accepted that skin wound healing runs in four characteristic stages: hemostasis, inflammation, proliferation, and maturation/remodeling. The initial phase called hemostasis, preventing blood loss, is immediately followed by the inflammatory phase, and therefore sometimes referred to as vascular reaction of the inflammatory phase [18]. Initial blood leakage triggers activation of otherwise inert zymogenes resulting in platelet activation and fibrin clot formation [19]. At the site of injury, platelets are stimulated by contact with subendothelium, tissue factors and collagens, leading to their degranulation [20] and release of proinflammatory molecules typical of initial wound healing phase involving interleukins (e.g., IL-4, IL-5, IL-6, IL-8, IL-13), chemokines (e.g., CXCL-4, CXCL8), growth factors (e.g., TGF- $\beta 1$, TGF- $\beta 2$, PDGF, IGF, EGF, VEGF, FGF), and TIMP-1 and TIMP-2 [21-25]. On the other hand, expression of antifibrotic factors is diminished (e.g., IFN- $\gamma$, IL-10, IL-12, TNF- $\alpha$ ). Importantly, the formed fibrin clot represents a permeable structure, which further facilitates migration of cells involved in wound healing, namely keratinocytes, immune cells and fibroblasts [26,27]. Of note, fibroblasts isolated from keloids express higher levels of chemokine receptors, making them more sensitive to migration stimuli [6]. 


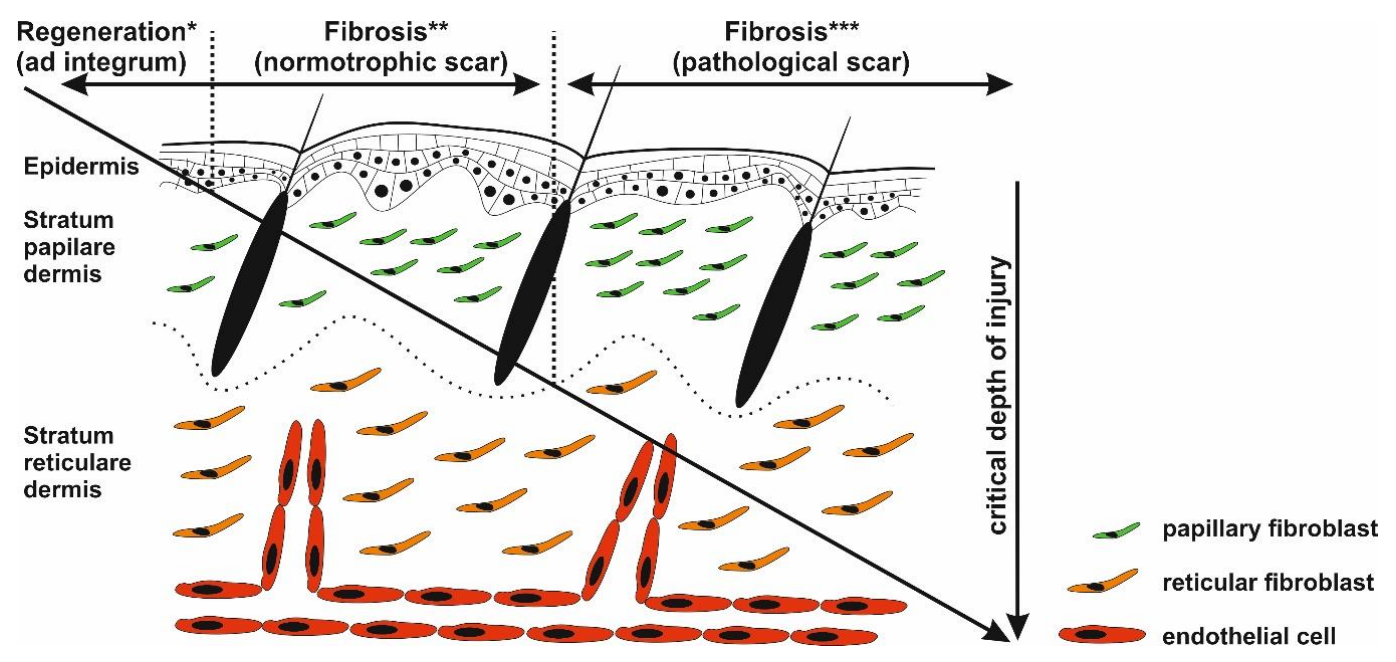

Figure 2. Critical depth of injury. Only the epidermis has the capability to fully regenerate $\left(^{*}\right)$, whereas healing of the injured dermis results in scar formation $\left(* *\right.$ and ${ }^{* * *}$ ). Injury targeting only papillary dermis ends with normotrophic scar formation $\left.{ }^{*}\right)$. Deeper wounds (reticular parts of the dermis) with prolonged inflammatory response may activate biological pathways resulting in pathological scarring $\left(^{* * *}\right)$.

\section{Immune Cells}

Neutrophils with over 30 different receptors responding to chemokines and other activation molecules (e.g., IL-8 and CXCL-8) are the first wound-infiltrating immune cells $[28,29]$. They represent the most abundant immune cell type responsible for pathogen and debris removal (forming the demarcation line separating dead/infected tissue from vital/healthy tissue) [30]. Neutrophils are capable of immune response amplification by recruitment of additional neutrophils (Figure 3) (by releasing TNF- $\alpha$, IL-1 $\beta$, IL-6, CXCL8, and CXL12) and macrophages (by releasing monocyte chemoattractant protein 1-MCP-1). Proteases secreted by neutrophils are able to degrade TGF- $\beta 1$ and PDGF, thereby arresting wound proliferation and remodeling processes [31]. In normal wounds, abundant neutrophils, which have completed their tasks, undergo apoptosis and are removed by local macrophages, resulting into inflammatory response attenuation [32,33]. However, in burn wounds, neutrophils hardly reach the site of injury due to the damage of blood vessels and lack of blood flow (Figure 4). Reduction in the average neutrophil migration speed [34] and low oxygen pressure [35] further complicates neutrophil navigation towards pathogens, resulting in a prolonged healing process in burned patients.

During normal skin wound healing, neutrophils are replaced by macrophages within a few days. The major source of wound-related macrophages is the pool of circulating monocytes in the blood vessels, which enter the injury site through vascular leakage, whereas skin-residing macrophages represent the minor source [36-38]. At the injury site, residing macrophages are polarized to inflammatory phenotype, sometimes referred to as M1 phenotype, as a response to the local presence of pathogens, necrotic tissue residues and various factors such as natural killer cell derived IFN- $\gamma[39,40]$. M1 macrophages secrete proinflammatory cytokines IL-1 $\beta$, IL-6, IL-12, IL-23, and TNF- $\alpha$, which further stimulate infiltrating monocytes [41-44]). The secreted IL-1 increases collagen synthesis and promotes fibroblast and keratinocyte proliferation [45]. However, M1-secreted TNF- $\alpha$ is linked to premature fibroblast senescence. Senescent fibroblasts contribute to wound chronicity by overproduction of proteases (e.g., MMP-2, MMP-3 and MMP-9) and decreased production of protease inhibitors [46]. To terminate inflammation during normal wound healing, a crucial transition of macrophages from proinflammatory M1 to anti-inflammatory M2 phenotype has to occur. A major contributor to the M2 phenotype polarization is efferocytosis, the process of used and abundant neutrophil phagocytosis by macrophages, which is further facilitated by other mediators such as prostaglandins, glucocorticoids, IL-4, IL-10, IL-13, adenosine, and microRNAs [47-51]. M2 macrophages have strong 
inflammation-resolving effects mediated by secretion of anti-inflammatory cytokines (e.g., IL-1 receptor antagonist, IL-10) and fibroblast proliferation and angiogenesis-stimulating effects by production of TGF- $\beta$ and VEGF [52].

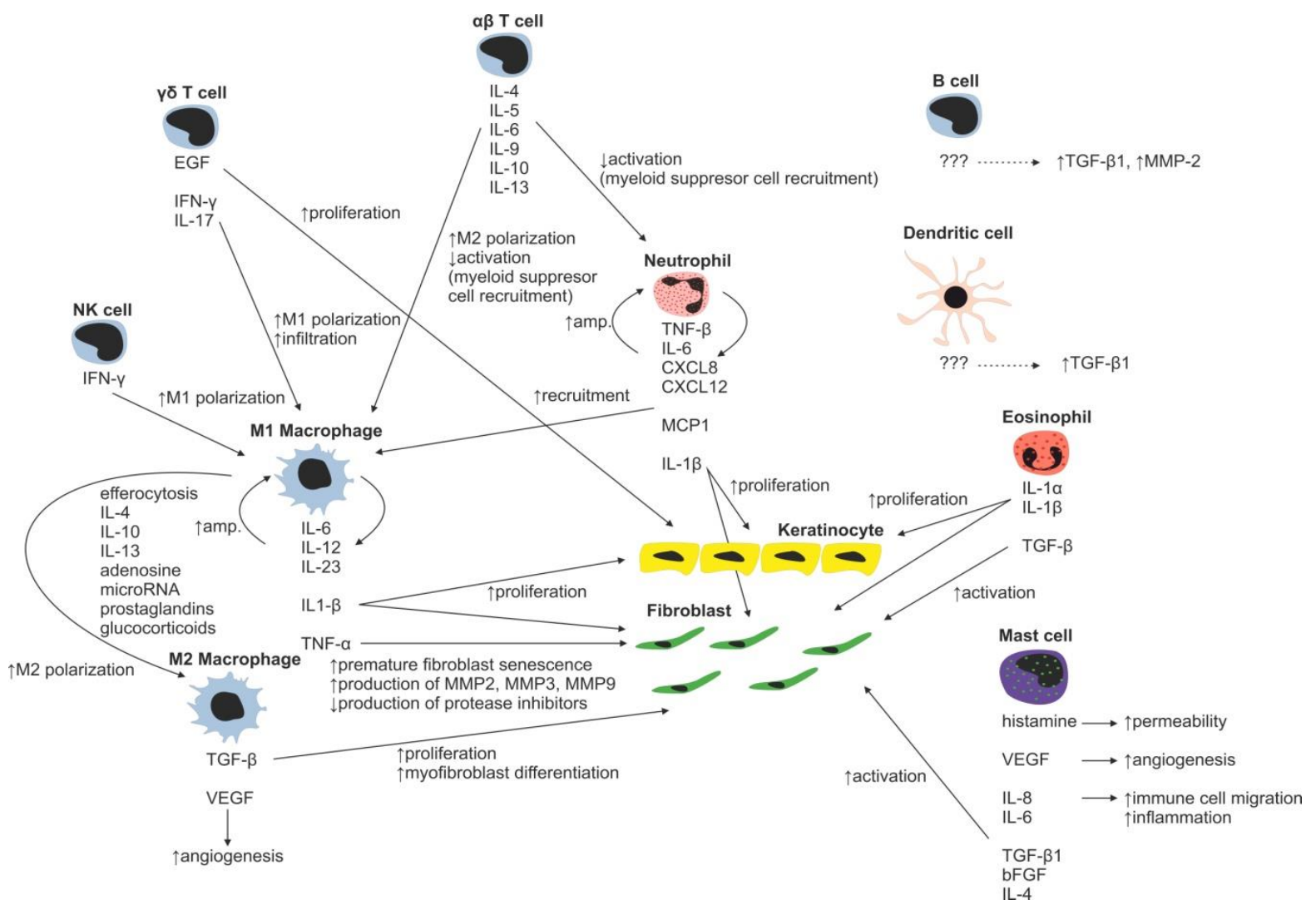

Figure 3. Immune cell regulation of normal wound healing.

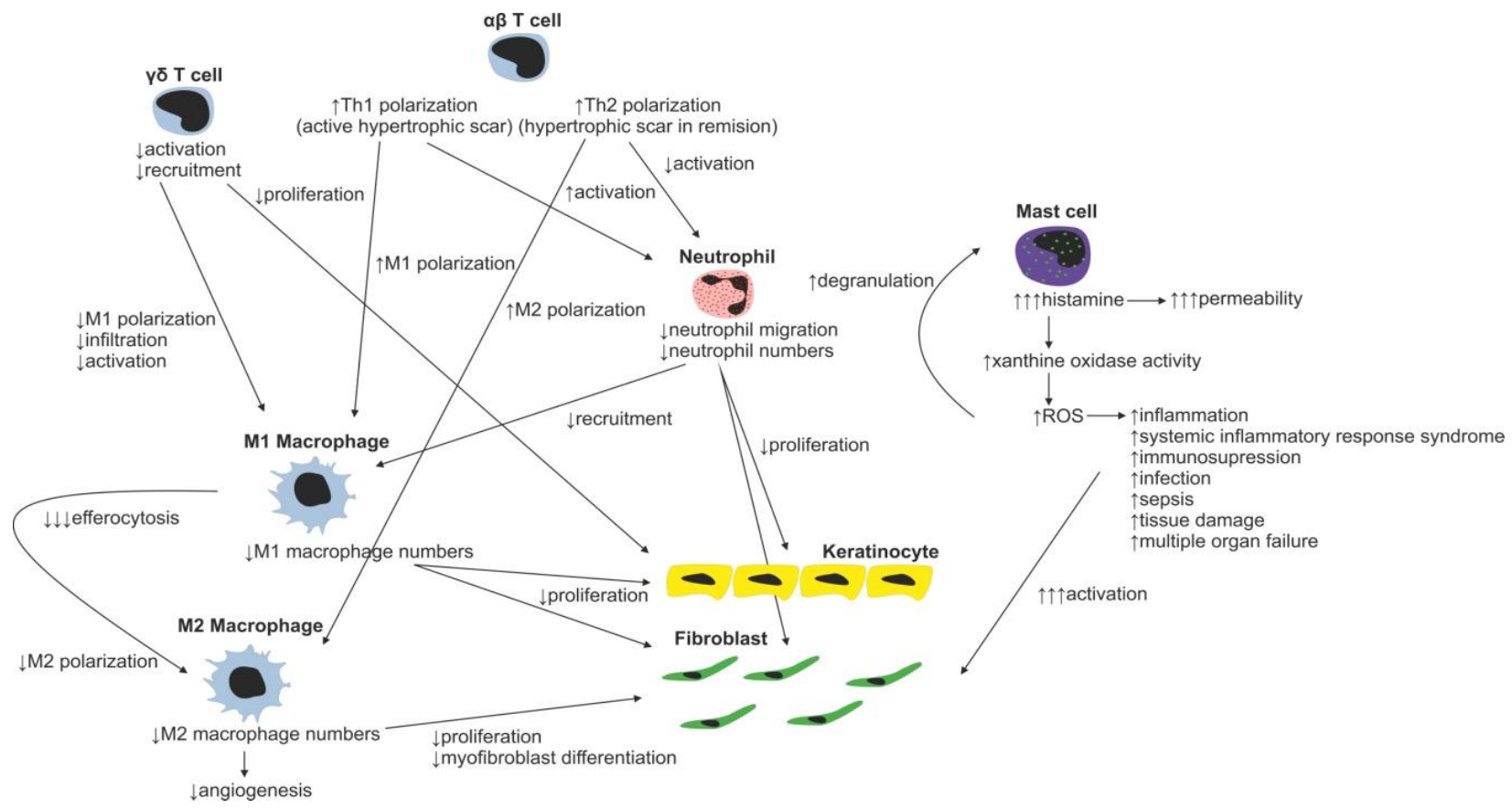

Figure 4. Changes in immune cell regulation of wound healing following burn injury. 
It is known that lack of macrophages, characteristically present in burns, negatively affects wound healing [53]. Not only are macrophages unable to reach the injury site analogically to neutrophils, the lack of neutrophils leads to imbalance in spent neutrophil efferocytosis, which in turn negatively affects macrophage M2 polarization and results in prolonged and/or unresolved chronic inflammation, delaying initiation of the proliferation phase [54]. Of note, macrophages may be polarized towards the M1 phenotype prior to entering the injury site as a response to altered wound microenvironment (WME). This prepolarization was also observed in nonhealing diabetic wounds (hyperglycemic conditions) and/or in patients with arterial/venous insufficiency (hypoxic conditions) with persisting chronic venous disease [54-56].

The role of various T-cell subsets throughout the wound-healing process and scar formation is much more intriguing. Epidermal $\gamma \delta \mathrm{T}$ cells residing at the injury site react to the tissue damage immediately by releasing epithelial growth factors and proinflammatory cytokines (IFN- $\gamma$, IL-17) [57], stimulating keratinocyte proliferation and immune cell infiltration. In normal wounds, $\gamma \delta \mathrm{T}$ cells contribute to early wound closure, whereas an absence of $\gamma \delta \mathrm{T}$ cells leads to impaired healing [58]. On the other hand, $\gamma \delta \mathrm{T}$ cell derived proinflammatory (IFN- $\gamma$, IL-17) $[59,60]$ cytokines promote early macrophage infiltration, which is associated with greater scar size, and thus it was hypothesized that $\gamma \delta$ T cells indirectly increase scarring [61]. In burns, $\gamma \delta$ T cell activation and recruitment are suppressed, leading to insufficient macrophage activation resulting in poor healing of the burn wound. Thus, the $\gamma \delta \mathrm{T}$ cell reactivation therapeutic approach has already been proposed in burn patients [62].

Contrary to $\gamma \delta \mathrm{T}$ cells, $\alpha \beta \mathrm{T}$ cells, another T-cell subset, play an important role in transition from the inflammatory to tissue maturation/remodeling phase of wound healing. $\alpha \beta$ T cells produce Th2 cytokines (e.g., IL-4, IL-5, IL-6, IL-9, IL-10 and IL-13) attenuating early inflammatory response by suppression of myeloid cell activation and myeloid suppressor cell recruitment [63], thus promoting Th2 polarization of T-cell subsets in WME. In normally healing wounds, the Th1 polarized T cells were shown to be predominantly present [64]. By contrast, in burn patients, the Th1 polarized T cells were found in active hypertrophic scars, whereas the Th2 phenotype was characteristic for the remission phase of hypertrophic scar formation [65]. In general, as a result of the postburn systemic response, an increase in serum levels of inflammatory cytokines TNF- $\alpha$, IL-8 and IL-6 is present in burned patients [66]. Moreover, it was shown that serum levels of IL-6, an interleukin strongly promoting Th2 differentiation [67], positively correlate with the severity of burn injury [68]. Even though the mechanism promoting Th2 polarization of $\mathrm{T}$ cells is rather multifactorial, the aforementioned $\alpha \beta$ T cells together with systemic response are probably the strongest contributors promoting this process. The impact of the systemic response on the T-cell population is remarkably evident three to seven days following a burn injury as a significant reduction in both CD4+ and CD8+ T-cell populations [69]. Furthermore, a decreased CD4:CD8 T-cell ratio was observed in burn wounds, most probably as a result of $\alpha \beta$ T-cell involvement in the burn wound pathogenesis [63]. A decrease in total T-cell numbers, diminished CD4:CD8 T-cell ratio, as well as anti-inflammatory Th2 T-cell polarization result in reduction of the T-cell dependent immune function in burn wounds [70]. Thus, the $\alpha \beta$ T-cell population has been proposed as an important therapeutic target for improving wound healing and recovery in burn patients [63].

Another well-studied immune cell population involved in the process of wound healing includes mast cells. Post-traumatically activated mast cells produce histamine, VEGF, IL-6 and IL-8, and thus increase endothelial permeability and facilitate migration of immune cells. Releasing IL-4, TGF- $\beta 1$ and bFGF, they activate fibroblasts to produce and organize collagen fibrils [71,72]. Moreover, mast cells are able to stimulate fibroblasts to myofibroblast differentiation, gap junction formation and ECM contraction [73-75]. Inhibition of mast cell activation in a murine wound-healing model resulted in reduced scar width and higher fibrillar density of ECM [76]. For example, second trimester fetal wounds, wounds that heal without scarring, contain less dermal mast cells with the 
absence of degranulation compared to third semester wounds [77]. Therefore, the high number of mast cells observed in hypertrophic scars, compared to normal scars, may present a potential therapeutic target to face the abundant scar tissue production [72] Burn injury stimulates mast cells to produce enormous amounts of histamine, which in turn enhances xanthine oxidase production of reactive oxygen species (ROS). ROS present in burns further strongly stimulate mast cell degranulation [78]. Huge production of ROS is dangerous due to its implications in inflammation, systemic inflammatory response syndrome, immunosuppression, infection and sepsis, tissue damage and multiple organ failure [79].

So far, only a few papers studying the role of dendritic and B cells in burn scar formation have appeared. B cells, when topically applied, increase TGF- $\beta$ and decrease MMP2 expressions in granulation tissue, improve healing, reduce scar size, increase collagen deposition and maturation, enhance angiogenesis, increase fibroblast proliferation and alter neutrophil infiltration $[80,81]$. Interestingly, it was shown that B-cell levels were significantly increased up to three and seven days post burn injury compared with healthy controls [69]. In this line of evidence, enhanced inflation of dendritic cells led to significantly accelerated wound closure, enhanced angiogenesis and cellular proliferation associated with increased TGF- $\beta 1$ levels. Similarly to B cells, wound enhancement with dendritic cells was suggested as a promising new therapeutic approach in burn injury treatment $[80,82]$.

So far, the role of other immune cell types in burn wound healing has not been comprehensively studied. For example, eosinophils secrete interleukins/growth factors IL$1 \alpha$, IL-1 $\beta$, TGF- $\beta 1$ promoting keratinocyte migration and are able to stimulate fibroblasts to upregulate $\alpha$-smooth muscle actin expression and collagen secretion [83]. However, the extent and molecular mechanism of the resulting effect of these cells on burn scar formation needs to be elucidated in further studies.

\section{Proliferation Phase of Wound Healing}

After pathogen removal and wound cleaning, the initial hemostasis/inflammation phase is followed by the proliferation phase, which usually occurs from days 4 to 21 [84] and is characterized by formation of granulation tissue. Initially, the recovering tissue is full of proliferating fibroblasts producing loose fibronectin-rich extracellular matrix [85]. Firstly formed collagen type III is slowly replaced during the maturation phase by collagen type I [86]. Finally, differentiated fibroblasts, myofibroblasts, accelerate wound closure by pulling wound margins together, mimicking action of smooth muscle cells [87]. In the meantime, epithelial cells migrate from the wound base to its top reproducing epidermis, a critical protective barrier, in a process also known as re-epithelialization [88]. The three key cell populations involved in the above-mentioned processes are fibroblasts/endothelial cells and keratinocytes, whose mutual interactions also known as epithelial-mesenchymal cross-talk are crucial for WME formation and wound healing outcome. Impairments in their interactions lead to excessive fibrotic scar formation and/or poor wound healing.

\subsection{Epidermis Regeneration}

Epidermis, the upper layer of the skin, is formed by multilayer growth of keratinocytes, which is continuously renewing itself. Keratinocytes originate from stem cells and mainly progenitor (transit-amplifying) cells located in the basal layer of the epidermis. These cells are characterized by expression of keratins 5 and 14 [89]. Stem cells, besides the basal layer, are also localized in the sweat glands and mainly in pilosebaceous units, in the region called bulge [90]. Epidermal stem cells are slow-cycling, label-retaining cells characterized by high expression of $\beta 1$-integrin, keratin 19, and absence of CD71 [91]. In partial-thickness wounds, where the deep dermal structures are preserved, stem cells from the bulge and sweat glands are responsible for the resurfacing of wounds resulting in fast and even re-epithelization [92]. In full-thickness wounds, where the whole dermis is completely destroyed, re-epithelization is restricted to migrating keratinocytes from the wound margins. The entire process of re-epithelization includes several basic steps. At the 
beginning, formation of provisional extracellular matrix by insoluble proteins is followed by migration, proliferation and stratification of keratinocytes. Already $24 \mathrm{~h}$ after injury, the activation of keratinocytes leads to hyperproliferative migratory phenotype characterized by expression of keratins 6, 16 and 17 [93]. Paracrine release of IL-1 triggers activation of keratinocytes, which are maintained in activated state by production of TNF- $\alpha$ [90]. Complete epidermis regeneration is characterized by reconstruction of dermo-epidermal junctions creating a barrier between the inner and outer environment [94], and swift re-epithelization thus prevents infection and scarring.

\section{Epithelial-to-Mesenchymal/Mesenchymal-to-Epithelial Transition}

Epithelial-to-mesenchymal transition (EMT) is a key process underlying the normal course of re-epithelialization, ECM deposition and early presence of myofibroblast(-like) cells in wounds $[95,96]$. The process of EMT in keratinocytes is initiated by the loss of tight junctions followed by E-cadherin (epithelial marker) switch to N-cadherin (mesenchymal marker) [97]. Subsequently, epithelial cells dramatically remodel the cytoskeleton, including de novo expression of $\alpha$-smooth muscle actin ( $\alpha$-SMA), vimentin and fibroblastspecific protein $1[97,98]$, resulting in the escape of newly formed mesenchymal cells away from the epidermis to facilitate scarring/fibrosis. Crucial E-cadherin-repressing and EMT-controlling factors involve transcription factors such as snail and slug (zinc finger proteins Snai1 and Snai2-formerly known as Slug) [99] and twist (basic helix-loop-helix protein) [100]. Further, EMT profibrotic repressors of E-cadherin also include zinc finger E-box-binding homeobox (ZEB) 1 and ZEB2 [101]. At the beginning, the EMT-derived myofibroblasts [102] promote wound contraction and deposit ECM, and thus promote skin repair. However, later, in particular during the unresolved prolonged inflammation [11], the EMT is provoked to produce new generations of cells producing excessive ECM contributing to hypertrophic scarring. Morphologically, the epidermis located over a hypertrophic scar is thicker, the mesechymal markers are upregulated, and the basement membrane is depredated [103]. The persistent presence of $\alpha$-SMA-expressing cells is thus typical of hypertrophic scars.

The in vitro 3D-organotypic full-thickness skin wound model [104] and a mouse model [105] revealed that only cells of the basal layer migrate in contact with the wound surface, whereas cells of the suprabasal layer move as a sheet without any dedifferentiation. The mouse study also identified the leading edge formed only of migrating keratinocytes followed by a proliferative hub containing both interfollicular and hair follicle-derived stem cells [105]. Asymmetric division of stem cells produces a high number of progenitor cells facilitating epidermis regeneration [106]. Re-epithelization is orchestrated by different signals produced by other cell populations, e.g., nitric oxide synthesized by macrophages, or a panel of growth factors such as EGF, HGF, bFGF, TGF- $\alpha$, and TGF- $\beta$ produced by fibroblasts $[107,108]$. The cell communication is bidirectional, and activated keratinocytes thus also influence surrounding fibroblasts, endothelial cells, melanocytes, and lymphocytes [109]. Migration and proliferation of keratinocytes is stopped by contact inhibition, when a stratified epidermis covers the entire skin defect [110]. Dermo-epidermal junctions are built up from the margins to the center and finally, basal keratinocytes turn back to the stationary phenotype with apical polarity [111].

Although data concerning wounded skin are limited, regulation of the stemness/ differentiation of cells by EMT is complemented and counterbalanced by a reverse process, mesenchymal-to-epithelial transition (MET) [112]. EMT, as described above, is a well-studied process involved in fibrosis, embryonic development, as well as in various hallmarks of cancer involving invasion, metastasis, stemness, and chemo-resistance [113]. Whereas inhibition of EMT has been extensively studied to overcome drug resistance and tumor dissemination [114,115], targeting MET presents a novel approach in cancer therapy [116]. So far, several MET-inducing or epithelial phenotype-enhancing transcription factors have been identified in cancer cells. Examples include Grainyhead-like protein 2 homolog (GRHL2) [117], Ovo-like (OVOL) family members [118,119], GATA-binding 
factor 3 (GATA3) [120], Forkhead Box A1 (FOXA1), FOXA3 [121] and Kruppel-like factor 4 (KLF4) [122]. However, MET induction in fibroblasts has been poorly studied. Mesenchymal phenotype in fibroblasts is preserved by DNA methylation [123], activity of specific barrier kinases [124] and microRNAs [125]. Thus, it has been suggested that activation of the intrinsic MET program may enhance [126] efficiency of the fibroblast to epithelial cell reprogramming. Only a few transcription factors activating MET in dermal fibroblasts have been identified, namely OVOL2, a potent MET enhancer, which was shown to induce MET in cooperation with already known reprogramming factors HNF1 homeobox A (HNF1A), tumor protein p63 (TP63) and KLF4 [126].

\subsection{Fibroblast, the Key Cell}

It has been shown that dermal fibroblasts are a heterogeneous population of mesenchymal cells (Table 1). In practical terms, fibroblasts are often defined by a combination of their morphology, tissue position and absence of endothelial, epithelial and leukocyte markers, whereas the intermediate filament vimentin and platelet-derived growth factor receptor- $\alpha$ (PDGFR $\alpha$ ) are typically present [127]. In parallel, CAFs have been defined by a specific subset of markers, including $\alpha$-SMA, tenascin C, fibroblast-specific protein-1, fibroblast activating protein, and neural-glial antigen [128]. Morphologically, we have recognized at least two distinct subgroups of normal skin fibroblasts, i.e., papillary and reticular (Figure 2), originating from one common precursor [129]. However, detailed single cell sequencing revealed up to six subgroups of dermal fibroblasts. Out of the identified populations, only fibroblasts expressing dipeptidylpeptidase IV are able to produce ECM, which is fundamental for wound healing [130]. Accordingly, the extent of scar formation depends on the transcriptomic profile of fibroblasts present in the wounds [131].

Table 1. Currently known differences between the main subpopulations of skin fibroblasts (- absent; + minimal; ++ mild; +++ moderate, ++++ marked, ? unknown).

\begin{tabular}{|c|c|c|c|c|}
\hline Parameter/Cell Type & $\begin{array}{c}\text { Papillary } \\
\text { Fibroblasts }\end{array}$ & $\begin{array}{c}\text { Reticular } \\
\text { Fibroblasts }\end{array}$ & $\begin{array}{c}\text { Hypertrophic } \\
\text { Fibroblasts }\end{array}$ & CAFs $^{1}$ \\
\hline cell size & + & ++ & + & + \\
\hline proliferation & ++ & + & ++ & $+/-$ \\
\hline collagen & ++ & ++ & ++ & ++++ \\
\hline collagenase activity & ++++ & + & + & $?$ \\
\hline$\alpha-S M A$ & + & +++ & +++ & +++ \\
\hline collagen contraction & + & +++ & +++ & +++ \\
\hline TGF- $\beta$ & + & + & + & + \\
\hline TGF- $\beta$ receptor 2 & + & +++ & +++ & $+/+++$ \\
\hline CTGF & + & +++ & +++ & ++++ \\
\hline osteopontin & + & +++ & +++ & +++ \\
\hline decorin & ++++ & + & + & +++ \\
\hline versican & + & +++ & +++ & ++++ \\
\hline
\end{tabular}

${ }^{1}$ CAF-cancer-associated fibroblast.

During the first phase of skin repair, local fibrocytes/fibroblasts are activated (by inflammatory factors) and (chemo)attracted (by a gradient) into the injury site [132]. Many of them differentiate into $\alpha$-SMA-expressing myofibroblasts (Figure 5) [133]. In addition, myofibroblasts may also be derived from other sources, for example, epithelial cells through the EMT, epidermal stem cells [134], bone marrow-derived mesenchymal stem cells [135], and from endothelial cells through the process called endothelial-mesenchymal transition [136]. 


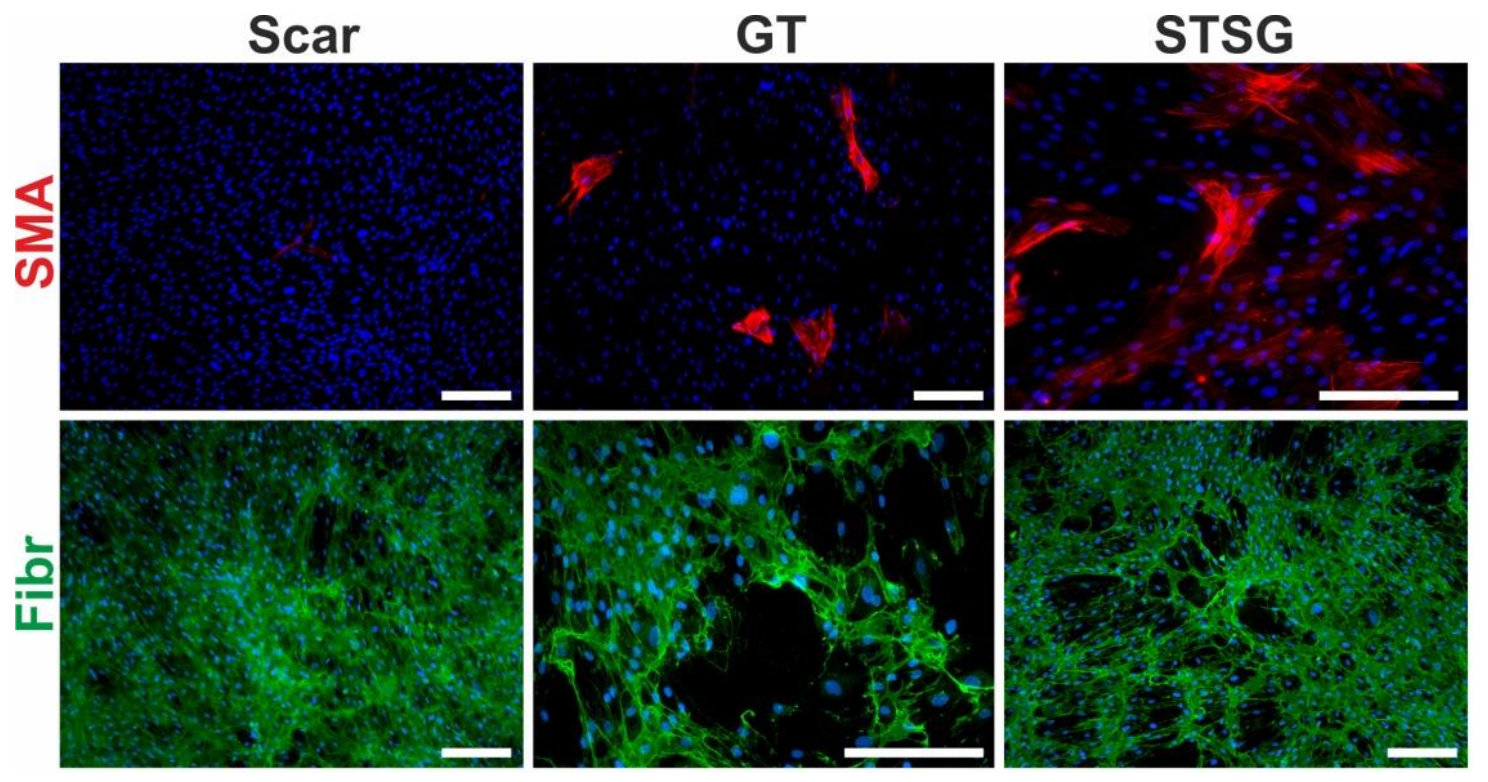

Figure 5. Primary cultures of human dermal fibroblasts isolated from matured scar (Scar), granulation tissue (GT) and split-thickness skin graft (STSG). Cultures were stained for $\alpha$-smooth muscle actin (SMA, red signal), fibronectin (Fibr, green signal) and nucleus (DAPI, blue signal) (scale bar $100 \mu \mathrm{m}$ ).

\section{ECM Deposition}

Deposition and reorganization of ECM leading to scar formation are part of a normal healing process. Fibroblasts and myofibroblasts are stimulated by several cytokines, growth factors and/or growth adhesion regulatory galectins (e.g., TGF- $\beta 1$, CTGF, PDGF, IGF, Gal-1, etc.). In detail, TGF- $\beta 1$ acts as the critical cytokine in fibroblast-to-myofibroblast differentiation, while Gal-1 is rather responsible for myofibroblast activation. In this context, it has been shown that the expression of Gal-1, primarily localized to $\alpha$-SMA-expressing myofibroblasts, increases substantially during skin wound healing and remains persistently elevated in hypertrophic scars [137]. They produce high amounts of structural components of the ECM (e.g., fibronectin, tenascin, collagen types III and I, etc.), which under normal circumstances are well regulated and their production decreases with the gradual overlap of proliferation phase to the maturation/remodeling phase of wound repair [138-141]. However, if the information is misregulated, for instance by prolonged inflammation in reticular dermis, abundant fibrotic tissue develops and a pathological scar is formed [142] Collagen synthesis is sevenfold higher in hypertrophic scars (20-fold in keloids) compared to the normal skin wounds [13]. The collagen I to III ratio in hypertrophic scars is 6:1, whereas in normal skin it is 5:1 (17:1 in keloids). Furthermore, collagen cross-links most frequently occur in keloids (twice as much as in hypertrophic scars), resulting in formation of typical thick hyalinized eosinophilic collagen bundles not seen in hypertrophic scars. Hypertrophic scars exhibit nodular collagen of rather regular fiber thickness with its long axis parallel to the epidermis, similarly as may be seen in keloids. Of note, the $\alpha$-SMAexpressing myofibroblasts are also variably expressed in both forms of scars [143]. Many other ECM components (e.g., fibronectin, hyaluronic acid, tenascin) are also increased in hypertrophic scars and keloids with certain variability [144].

\subsection{Angiogenesis}

Angiogenesis, development of new capillaries from preexisting vessels leading to microvascular network creation, is a crucial process in wound healing providing nutrients and oxygen to the damaged tissue [145]. Several angiogenesis stimulators have been discovered so far, namely, FGF $\alpha$ (FGF-1), bFGF (FGF-2), TGF- $\alpha$, TGF- $\beta$, PGE2, TNF- $\alpha$, VEGF, and EGF [146-153]. On the other hand, thrombospondin-1, connective tissue growth factor, tissue inhibitors of metalloproteinases, interferon- $\alpha$, interferon- $\beta$, interferon- $\gamma$, 
angiostatin, and endostatin were identified as inhibitors of angiogenesis [145,154-158]. In burn wounds, however, the most potent stimulator of neovascularization is HIF-1 [159], as well as VEGF and CXCL12 (C-X-C motif chemokine 12 also known as stromal cellderived factor 1) [160]. Moreover, angiogenesis in burned patients is sustained by an elevated blood level of endothelial progenitor cells corresponding to the size of traumatized area [161]. The best studied angiogenesis stimulator, VEGF, acts as a vascular endothelial cell mitogen, potent vasodilator and factor increasing microvascular permeability, as well as a regulator of endothelial integrins during vessel sprouting $[147,162]$. Sprouting requires the activity of MMPs regulating degradation of ECM surrounding the original vessel, so that the exposed tip cells may migrate into the newly formed granulation tissue forming a new sprout. On the downside, to compensate for the loss of the degraded ECM, the residing fibroblasts produce collagen leading to increased deposition of the scar tissue. VEGF was also shown to upregulate expression of adhesion molecules on the surface of endothelial cells, in addition to VEGF-mediated vasopermeabilization. This supports leukocyte extravasation $[163,164]$, a process of immune cell passage through the vessel wall. From this point of view, VEGF also indirectly supports scar formation through recruitment of macrophages and mast cells, immune cells which were found to promote excessive scar formation vastly present in hypertrophic scars and keloids $[76,164,165]$ by a mechanism remarkably similar to that of proinflammatory cytokines [166-168]. In addition, VEGF may act as a chemokine and directly activate macrophages due to VEGFR (receptors for vascular endothelial growth factor) expression on their surface [168]. Although evidence points to the VEGF involvement in the scar tissue formation [169-174]), the exact mechanism of how VEGF promotes/regulates the scar formation has not been completely understand. Data published so far suggest that anti-VEGF treatment could minimize scarring, yet this hypothesis needs to be further evaluated in animal models of hypertrophic scarring and human clinical trials.

\section{Maturation and Remodeling Phase of Wound Healing}

It is well known that scar remodeling may last up to several years. Failure of the maturation and modeling phase may result in excessive collagen accumulation and formation of hypertrophic scars with enormous rigidity (Figure 6), or even in formation of a specific, not easily treatable unit-keloid. The connective tissue of keloid is morphologically similar to desmoplastic stroma of some tumors, especially of pancreatic adenocarcinoma [175]. In this context, fibroblasts isolated from keloids are very similar to cancer-associated fibroblasts isolated from the tumor stroma not only by expression of $\alpha$-SMA, but also by expression of transcripts encoding inflammation-supporting cytokines and/or chemokines [176]. Due to the morphological similarity of keloids and tumors, cutaneous leiomyomas may sometimes be misdiagnosed as keloids and vice versa [177]. Of note, inhibitor of receptor kinase nintedanib, which is used in cancer therapy, is also effective in the treatment of therapy-refractive keloids [178].

If cells capable of generating mechanical forces are still present in activated state, contraction may graduate and results in poor cosmetic and/or functional deterioration of organs/tissues including the skin [179]. Furthermore, abnormal mechanical stresses in the wound microenvironment also induce hypertrophic scarring via activation of mechanotransduction pathways that include, but are not restricted to, integrin, Wingless-type, protein kinase $B$, and focal adhesion kinase, resulting in excessive cell proliferation, ECM formation, and finally fibrosis [180]. Fibroblasts are the main affected cell population, where mechanical force upregulates several profibrotic genes encoding proteins such as TGF- $\beta 1 / 2, \alpha$-SMA (Figure 6 ) and collagen I through different mechanoreceptors (integrins, growth factor receptors, $G$ protein-coupled receptors, and ion channels). Therefore, it was not surprising to see that neutralization of TGF- $\beta 1 / 2$ or exogenous addition of TGF- $\beta 3$ reduced ECM deposition and scarring in a rat model [181]. Differentiated/activated myofibroblasts adhere to the ECM via cell surface receptors that transmit contractile forces leading to scar contracture [182]. Of note, the integrin-focal adhesion kinase (FAK) path- 
way plays a central role in the regulation of skin mechanotransduction. Mechanical forces during wound repair and/or scar formation activate the FAK pathway leading to intracellular signaling by numerous downstream factors (PI3K and MAPK kinases) mediating the fibrotic responses [183]. Thus, decreased FAK signaling was seen in nonhealing wounds, while FAK overactivation results in hypertrophic scar formation.

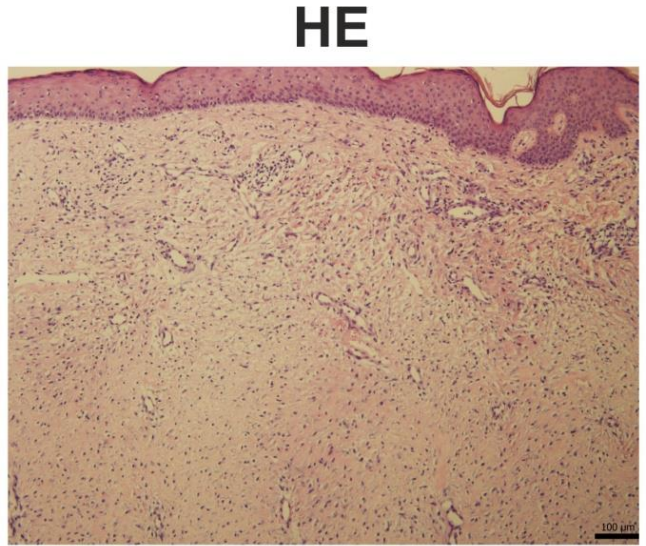

CD45

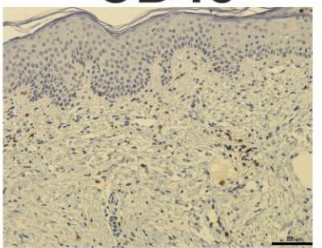

CD31

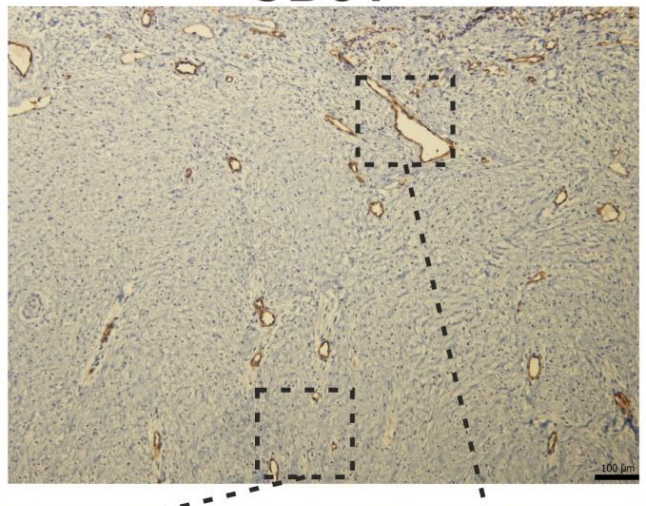

(106)

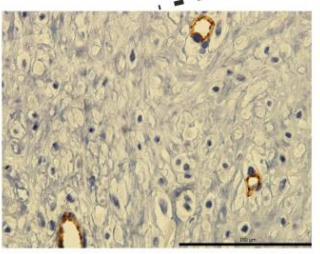

CD3
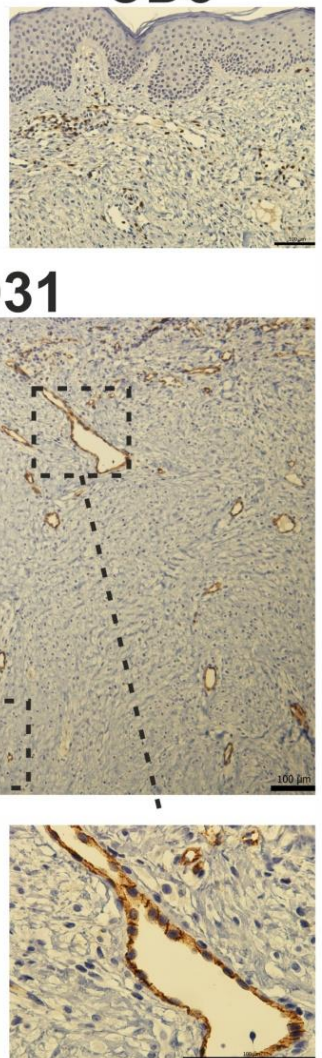

SR (pol)

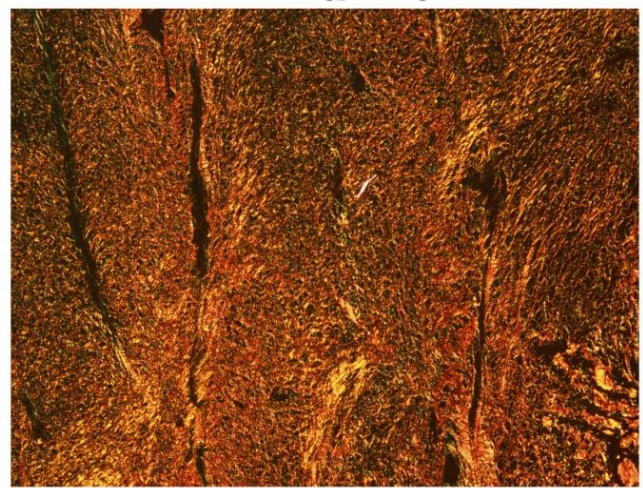

CD4

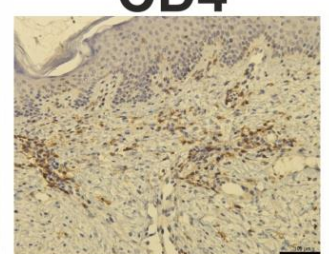

CD8

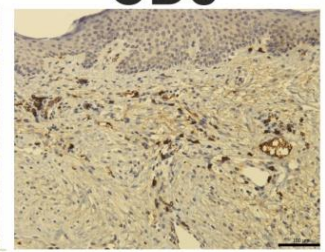

SMA
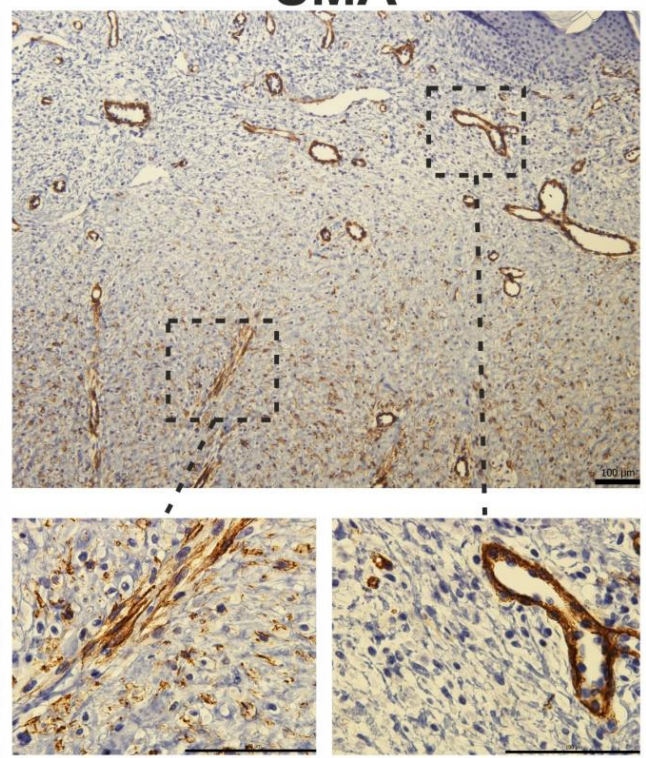

Figure 6. Histological photomicrograph of a hypertrophic scar stained with hematoxylin-eosin (HE) and Sirius red (SR) observed under polarized light (pol). Immunohistochemical staining of a hypertrophic scar. Prolonged inflammation results in the presence of CD45-positive cells in fibrotic tissue. CD3 staining showed characteristic T-cell islands, which were more pronounced after selective staining of CD4 and CD8-expressing T-cell subpopulations. The presence of myofibroblasts is restricted to deeper parts of the scar: in detail, $\alpha$-smooth muscle actin (SMA) positivity was seen in luminized vessels (also positive for endothelial marker CD31), whereas CD31-negative and SMAexpressing cells (myofibroblasts) were located rather in the deeper parts of the scars (scale $100 \mu \mathrm{m}$ ). 


\section{Conclusions}

Wound healing represents a well-organized cascade of events that primarily aims to restore the barrier/protective function of the skin to avoid further blood loss and infection. Fibrosis and regeneration may be considered as counterparts regarding functional and cosmetic outcomes of wound repair. Normal wound healing is always a compromise between fibrosis and regeneration, carried out in a spectrum of events from hypertrophic repair, typical of young individuals following deep burns, to full regeneration seen in fetal wound healing. Therefore, complete understanding of the molecular mechanisms underlying the balance of fibrosis vs regeneration is the key to further therapy towards scarless healing in a fully controlled manner. Similarly, tumor growth and spreading is in many aspects similar to wound repair, as previously defined by Harold Dvorak $[184,185]$. The tumor vs wound parallel is also well documented in an example of signaling molecules [107]. From this point of view, study of both processes may be useful to better understanding of the biological issues related to poor healing in order to employ them in more efficient clinical practice. In addition, remarkable similarities between the behavior of keloid and cancer concerning their independent locally aggressive growth and resistance to treatment have been reported and their similarity at the cell/molecular biology level was shown in various features of cancer [186-188]. This relationship between both processes can be clearly demonstrated at the chemokine signaling level [189], of which the TGF- $\beta$ family is the most distinguished representative [190].

Hence, signal cascades involving cell-matrix and cell-cell interactions in WME are crucial for future controlled clinical approaches preventing formation of excessive scars and directing the repair process towards regeneration, fully restoring the original functions of the skin.

Author Contributions: Conceptualization: M.Č. and P.G.; data collection: M.Č., L.F., L.U., T.U., R.Z., P.S., Š.N., V.F., B.D., K.S.J., P.G.; writing—original draft preparation: M.Č., R.Z., P.S., B.D., K.S.J., P.G.; funding acquisition: K.S.J. and P.G. All authors have read and agreed to the published version of the manuscript.

Funding: Data shown in this review were obtained with the support of the Slovak Research and Development Agency under contract Nos. APVV-14-0731 and APVV-16-0207, Slovak Grant Agency (VEGA-1/0561/18), Charles University (PROGRES Q28 and Q37), Operational Programme Research, Development and Education ("Center for Tumor Ecology - Research of the Cancer Microenvironment Supporting Cancer Growth and Spread", No. CZ.02.1.01/0.0/0.0/16_019/0000785), Medical University Science Park in Košice (MediPark - Phase II) ITMS2014+ 313011D103 supported by Operational Programme Research \& Innovation, funded by ERDF, and COST Action CA18103 (InnoGly).

Acknowledgments: Authors are grateful to Jarka Kosorínová (Department of Pathology, L. Pasteur University Hospital in Košice) for their expert technical assistance and to Šárka Takáčová for English revision.

Conflicts of Interest: The authors declare no conflict of interest.

$\begin{array}{ll}\text { Abbreviations } \\ \text { aFGF } & \text { Acidic fibroblast growth factor } \\ \text { bFGF } & \text { Basic fibroblast growth factor } \\ \text { CAF } & \text { Cancer-associated fibroblast } \\ \text { CD } & \text { Cluster of differentiation } \\ \text { CTGF } & \text { Connective tissue growth factor } \\ \text { CXCL } & \text { Chemokine ligand } \\ \text { ECM } & \text { Extracellular matrix } \\ \text { EGF } & \text { Epidermal growth factor } \\ \text { EMT } & \text { Epithelial-mesenchymal transition } \\ \text { FAK } & \text { Focal adhesion kinase } \\ \text { Fibr } & \text { Fibronectin }\end{array}$




$\begin{array}{ll}\text { FOXA } & \text { Forkhead Box A } \\ \text { Gal } & \text { Galectin } \\ \text { GRHL2 } & \text { Grainyhead-like protein 2 homolog } \\ \text { GATA } & \text { guanine, adenine, thymine, adenine } \\ \text { GT } & \text { Granulation tissue } \\ \text { HGF } & \text { Hepatocyte growth factor } \\ \text { HIF } & \text { Hypoxia inducible factor } \\ \text { HNF1A } & \text { HNF1 homeobox A } \\ \text { IGF } & \text { Insulin growth factor } \\ \text { IL } & \text { Interleukin } \\ \text { IFN } & \text { Interferon } \\ \text { KLF4 } & \text { Kruppel-like factor 4 } \\ \text { MAPK } & \text { Mitogen-activated protein kinase } \\ \text { MET } & \text { Mesenchymal-to-epithelial transition } \\ \text { MMP } & \text { Matrix metalloproteinase } \\ \text { OVOL2 } & \text { Ovo-like 2 } \\ \text { PDGF } & \text { Platelet-derived growth factor } \\ \text { PGE2 } & \text { Prostaglandin E2 } \\ \text { PI3K } & \text { Phosphoinositide 3-kinase } \\ \text { ROS } & \text { Reactive oxygen species } \\ \text { SMA } & \text { Smooth muscle actin } \\ \text { STSG } & \text { Split thickness skin graft } \\ \text { TIMP } & \text { Tissue inhibitor of matrix metalloproteinase } \\ \text { TGF } & \text { Transforming growth factor } \\ \text { TNF } & \text { Tumor necrosis factor } \\ \text { TP63 } & \text { Tumor protein p63 } \\ \text { VEGF } & \text { Vascular endothelial growth factor } \\ \text { VEGFR } & \text { Vascular endothelial growth factor receptor } \\ \text { WME } & \text { Wound microenvironment } \\ & \end{array}$

\section{References}

1. Bayat, A.; McGrouther, D.A.; Ferguson, M.W. Skin scarring. BMJ 2003, 326, 88-92. [CrossRef] [PubMed]

2. Tsao, S.S.; Dover, J.S.; Arndt, K.A.; Kaminer, M.S. Scar management: Keloid, hypertrophic, atrophic, and acne scars. Semin. Cutan. Med. Surg 2002, 21, 46-75. [CrossRef] [PubMed]

3. Bell, L.; McAdams, T.; Morgan, R.; Parshley, P.F.; Pike, R.C.; Riggs, P.; Carpenter, J.E. Pruritus in burns: A descriptive study. J. Burn Care Rehabil. 1988, 9, 305-308. [PubMed]

4. $\quad$ Robert, R.; Blakeney, P.; Villarreal, C.; Meyer, W.J., 3rd. Anxiety: Current practices in assessment and treatment of anxiety of burn patients. Burns 2000, 26, 549-552. [CrossRef]

5. Taal, L.A.; Faber, A.W. Posttraumatic stress and maladjustment among adult burn survivors 1-2 years postburn. Burns 1998, 24, 285-292. [CrossRef]

6. Slemp, A.E.; Kirschner, R.E. Keloids and scars: A review of keloids and scars, their pathogenesis, risk factors, and management. Curr. Opin. Pediatr. 2006, 18, 396-402. [CrossRef]

7. Atiyeh, B.S. Nonsurgical management of hypertrophic scars: Evidence-based therapies, standard practices, and emerging methods. Aesthetic. Plast. Surg. 2007, 31, 468-492; discussion 493-464. [CrossRef]

8. Lindley, L.E.; Stojadinovic, O.; Pastar, I.; Tomic-Canic, M. Biology and biomarkers for wound healing. Plast. Reconstr. Surg. 2016, 138, 18S-28S. [CrossRef]

9. Gauglitz, G.G.; Korting, H.C.; Pavicic, T.; Ruzicka, T.; Jeschke, M.G. Hypertrophic scarring and keloids: Pathomechanisms and current and emerging treatment strategies. Mol. Med. 2011, 17, 113-125. [CrossRef]

10. Berman, B.; Maderal, A.; Raphael, B. Keloids and hypertrophic scars: Pathophysiology, classification, and treatment. Dermatol. Surg. 2017, 43 (Suppl 1), S3-S18. [CrossRef]

11. Ogawa, R. Keloid and hypertrophic scars are the result of chronic inflammation in the reticular dermis. Int. J. Mol. Sci. 2017, 18, 606. [CrossRef] [PubMed]

12. Niessen, F.B.; Schalkwijk, J.; Vos, H.; Timens, W. Hypertrophic scar formation is associated with an increased number of epidermal langerhans cells. J. Pathol. 2004, 202, 121-129. [CrossRef] [PubMed]

13. Xue, M.; Jackson, C.J. Extracellular matrix reorganization during wound healing and its impact on abnormal scarring. Adv. Wound Care 2015, 4, 119-136. [CrossRef] [PubMed]

14. Gurtner, G.C.; Dauskardt, R.H.; Wong, V.W.; Bhatt, K.A.; Wu, K.; Vial, I.N.; Padois, K.; Korman, J.M.; Longaker, M.T. Improving cutaneous scar formation by controlling the mechanical environment: Large animal and phase i studies. Ann. Surg. 2011, 254, 217-225. [CrossRef] 
15. Meyer, M.; McGrouther, D.A. A study relating wound tension to scar morphology in the pre-sternal scar using langers technique. Br. J. Plast. Surg. 1991, 44, 291-294. [CrossRef]

16. Wray, R.C. Force required for wound closure and scar appearance. Plast. Reconstr. Surg. 1983, 72, 380-382. [CrossRef] [PubMed]

17. Farina, J.A., Jr.; Rosique, M.J.; Rosique, R.G. Curbing inflammation in burn patients. Int. J. Inflam. 2013, 2013, 715645. [CrossRef]

18. Schultz, G.S.; Chin, G.A.; Moldawer, L.; Diegelmann, R.F. Principles of wound healing. In Mechanisms of Vascular Disease: A Reference Book for Vascular Specialists; Fitridge, R., Thompson, M., Eds.; University of Adelaide Press: Adelaide, SA, Australia, 2011.

19. Smith, S.A.; Travers, R.J.; Morrissey, J.H. How it all starts: Initiation of the clotting cascade. Crit. Rev. Biochem Mol. Biol. 2015, 50, 326-336. [CrossRef]

20. Wang, P.H.; Huang, B.S.; Horng, H.C.; Yeh, C.C.; Chen, Y.J. Wound healing. J. Chin. Med. Assoc. 2018, 81, 94-101. [CrossRef]

21. Niessen, F.B.; Spauwen, P.H.; Schalkwijk, J.; Kon, M. On the nature of hypertrophic scars and keloids: A review. Plast. Reconstr. Surg. 1999, 104, 1435-1458. [CrossRef]

22. Balaji, S.; Watson, C.L.; Ranjan, R.; King, A.; Bollyky, P.L.; Keswani, S.G. Chemokine involvement in fetal and adult wound healing. Adv. Wound Care 2015, 4, 660-672. [CrossRef] [PubMed]

23. Martins-Green, M.; Petreaca, M.; Wang, L. Chemokines and their receptors are key players in the orchestra that regulates wound healing. Adv. Wound Care 2013, 2, 327-347. [CrossRef] [PubMed]

24. Fivenson, D.P.; Faria, D.T.; Nickoloff, B.J.; Poverini, P.J.; Kunkel, S.; Burdick, M.; Strieter, R.M. Chemokine and inflammatory cytokine changes during chronic wound healing. Wound Repair. Regen. 1997, 5, 310-322. [CrossRef] [PubMed]

25. Palta, S.; Saroa, R.; Palta, A. Overview of the coagulation system. Ind. J. Anaesth. 2014, 58, 515-523. [CrossRef]

26. Reinke, J.M.; Sorg, H. Wound repair and regeneration. Eur. Surg. Res. 2012, 49, 35-43. [CrossRef]

27. Ozgok Kangal, M.K.; Regan, J.P. Wound healing. In Statpearls; StatPearls Publishing: Treasure Island, FL, USA, 2020.

28. Lin, F.; Nguyen, C.M.; Wang, S.J.; Saadi, W.; Gross, S.P.; Jeon, N.L. Effective neutrophil chemotaxis is strongly influenced by mean il-8 concentration. Biochem. Biophys. Res. Commun. 2004, 319, 576-581. [CrossRef]

29. Futosi, K.; Fodor, S.; Mocsai, A. Neutrophil cell surface receptors and their intracellular signal transduction pathways. Int. Immunopharmacol. 2013, 17, 638-650. [CrossRef]

30. De Oliveira, S.; Rosowski, E.E.; Huttenlocher, A. Neutrophil migration in infection and wound repair: Going forward in reverse. Nat. Rev. Immunol. 2016, 16, 378-391. [CrossRef]

31. Zhao, R.; Liang, H.; Clarke, E.; Jackson, C.; Xue, M. Inflammation in chronic wounds. Int. J. Mol. Sci 2016, 17, 2085. [CrossRef]

32. Serhan, C.N.; Chiang, N.; Van Dyke, T.E. Resolving inflammation: Dual anti-inflammatory and pro-resolution lipid mediators. Nat. Rev. Immunol. 2008, 8, 349-361. [CrossRef]

33. Widgerow, A.D. Cellular resolution of inflammation-Catabasis. Wound Repair Regen. 2012, 20, 2-7. [CrossRef] [PubMed]

34. Butler, K.L.; Ambravaneswaran, V.; Agrawal, N.; Bilodeau, M.; Toner, M.; Tompkins, R.G.; Fagan, S.; Irimia, D. Burn injury reduces neutrophil directional migration speed in microfluidic devices. PLoS ONE 2010, 5, e11921. [CrossRef] [PubMed]

35. Egners, A.; Erdem, M.; Cramer, T. The response of macrophages and neutrophils to hypoxia in the context of cancer and other inflammatory diseases. Mediat. Inflamm. 2016, 2016, 2053646. [CrossRef] [PubMed]

36. Rodero, M.P.; Legrand, J.M.; Bou-Gharios, G.; Khosrotehrani, K. Wound-associated macrophages control collagen 1alpha2 transcription during the early stages of skin wound healing. Exp. Dermatol. 2013, 22, 143-145. [CrossRef]

37. Rodero, M.P.; Licata, F.; Poupel, L.; Hamon, P.; Khosrotehrani, K.; Combadiere, C.; Boissonnas, A. In vivo imaging reveals a pioneer wave of monocyte recruitment into mouse skin wounds. PLoS ONE 2014, 9, e108212. [CrossRef]

38. MacDonald, K.P.; Palmer, J.S.; Cronau, S.; Seppanen, E.; Olver, S.; Raffelt, N.C.; Kuns, R.; Pettit, A.R.; Clouston, A.; Wainwright, B.; et al. An antibody against the colony-stimulating factor 1 receptor depletes the resident subset of monocytes and tissue- and tumor-associated macrophages but does not inhibit inflammation. Blood 2010, 116, 3955-3963. [CrossRef]

39. Adams, D.O. Molecular interactions in macrophage activation. Immunol. Today 1989, 10, 33-35. [CrossRef]

40. Adams, D.O.; Koerner, T.J. Gene regulation in macrophage development and activation. Year Immunol. 1989, 4, 159-180.

41. Martinez, F.O.; Sica, A.; Mantovani, A.; Locati, M. Macrophage activation and polarization. Front. Biosci. 2008, $13,453-461$. [CrossRef]

42. Verreck, F.A.; de Boer, T.; Langenberg, D.M.; Hoeve, M.A.; Kramer, M.; Vaisberg, E.; Kastelein, R.; Kolk, A.; de Waal-Malefyt, R.; Ottenhoff, T.H. Human il-23-producing type 1 macrophages promote but il-10-producing type 2 macrophages subvert immunity to (myco)bacteria. Proc. Natl. Acad. Sci. USA 2004, 101, 4560-4565. [CrossRef]

43. Sica, A.; Mantovani, A. Macrophage plasticity and polarization: In vivo veritas. J. Clin. Investig. 2012, 122, 787-795. [CrossRef] [PubMed]

44. Sica, A.; Porta, C.; Morlacchi, S.; Banfi, S.; Strauss, L.; Rimoldi, M.; Totaro, M.G.; Riboldi, E. Origin and functions of tumorassociated myeloid cells (tamcs). Cancer Microenviron. 2012, 5, 133-149. [CrossRef] [PubMed]

45. Zaja-Milatovic, S.; Richmond, A. Cxc chemokines and their receptors: A case for a significant biological role in cutaneous wound healing. Histol. Histopathol. 2008, 23, 1399-1407. [PubMed]

46. Mendez, M.V.; Stanley, A.; Park, H.Y.; Shon, K.; Phillips, T.; Menzoian, J.O. Fibroblasts cultured from venous ulcers display cellular characteristics of senescence. J. Vasc. Surg. 1998, 28, 876-883. [CrossRef]

47. Elliott, M.R.; Koster, K.M.; Murphy, P.S. Efferocytosis signaling in the regulation of macrophage inflammatory responses. J. Immunol. 2017, 198, 1387-1394. [CrossRef] [PubMed] 
48. Fadok, V.A.; Bratton, D.L.; Konowal, A.; Freed, P.W.; Westcott, J.Y.; Henson, P.M. Macrophages that have ingested apoptotic cells in vitro inhibit proinflammatory cytokine production through autocrine/paracrine mechanisms involving tgf-beta, pge2, and paf. J. Clin. Investig. 1998, 101, 890-898. [CrossRef] [PubMed]

49. Landen, N.X.; Li, D.; Stahle, M. Transition from inflammation to proliferation: A critical step during wound healing. Cell Mol. Life Sci. 2016, 73, 3861-3885. [CrossRef]

50. Liu, W.; Shahid, M.Q.; Bai, L.; Lu, Z.Z.; Chen, Y.H.; Jiang, L.; Diao, M.Y.; Liu, X.D.; Lu, Y.G. Evaluation of genetic diversity and development of a core collection of wild rice (oryza rufipogon griff.) populations in china. PLoS ONE 2015, 10, e0145990. [CrossRef]

51. Nosbaum, A.; Prevel, N.; Truong, H.A.; Mehta, P.; Ettinger, M.; Scharschmidt, T.C.; Ali, N.H.; Pauli, M.L.; Abbas, A.K.; Rosenblum, M.D. Cutting edge: Regulatory t cells facilitate cutaneous wound healing. J. Immunol. 2016, 196, 2010-2014. [CrossRef]

52. Brancato, S.K.; Albina, J.E. Wound macrophages as key regulators of repair: Origin, phenotype, and function. Am. J. Pathol. 2011, 178, 19-25. [CrossRef]

53. Xiu, F.; Jeschke, M.G. Perturbed mononuclear phagocyte system in severely burned and septic patients. Shock 2013, 40, 81-88. [CrossRef] [PubMed]

54. Hesketh, M.; Sahin, K.B.; West, Z.E.; Murray, R.Z. Macrophage phenotypes regulate scar formation and chronic wound healing. Int. J. Mol. Sci. 2017, 18, 1545. [CrossRef] [PubMed]

55. Sindrilaru, A.; Peters, T.; Wieschalka, S.; Baican, C.; Baican, A.; Peter, H.; Hainzl, A.; Schatz, S.; Qi, Y.; Schlecht, A.; et al. An unrestrained proinflammatory $\mathrm{m} 1$ macrophage population induced by iron impairs wound healing in humans and mice. J. Clin. Investig. 2011, 121, 985-997. [CrossRef] [PubMed]

56. Ellis, S.; Lin, E.J.; Tartar, D. Immunology of wound healing. Curr. Dermatol. Rep. 2018, 7, 350-358. [CrossRef] [PubMed]

57. Nomura, T.; Kabashima, K.; Miyachi, Y. The panoply of alphabetat cells in the skin. J. Dermatol. Sci. 2014, 76, 3-9. [CrossRef] [PubMed]

58. Havran, W.L.; Jameson, J.M. Epidermal t cells and wound healing. J. Immunol. 2010, 184, 5423-5428. [CrossRef]

59. Jensen, K.D.; Su, X.; Shin, S.; Li, L.; Youssef, S.; Yamasaki, S.; Steinman, L.; Saito, T.; Locksley, R.M.; Davis, M.M.; et al. Thymic selection determines gammadelta $t$ cell effector fate: Antigen-naive cells make interleukin-17 and antigen-experienced cells make interferon gamma. Immunity 2008, 29, 90-100. [CrossRef]

60. Schmolka, N.; Wencker, M.; Hayday, A.C.; Silva-Santos, B. Epigenetic and transcriptional regulation of gammadelta t cell differentiation: Programming cells for responses in time and space. Semin. Immunol. 2015, 27, 19-25. [CrossRef]

61. Larouche, J.; Sheoran, S.; Maruyama, K.; Martino, M.M. Immune regulation of skin wound healing: Mechanisms and novel therapeutic targets. Adv. Wound Care 2018, 7, 209-231. [CrossRef]

62. Schwacha, M.G. Gammadelta t-cells: Potential regulators of the post-burn inflammatory response. Burns 2009, 35, 318-326. [CrossRef]

63. Rani, M.; Schwacha, M.G. The composition of t-cell subsets are altered in the burn wound early after injury. PLoS ONE 2017, 12, e0179015. [CrossRef] [PubMed]

64. Boyce, D.E.; Jones, W.D.; Ruge, F.; Harding, K.G.; Moore, K. The role of lymphocytes in human dermal wound healing. Br. J. Dermatol. 2000, 143, 59-65. [CrossRef] [PubMed]

65. Bernabei, P.; Rigamonti, L.; Ariotti, S.; Stella, M.; Castagnoli, C.; Novelli, F. Functional analysis of tymphocytes infiltrating the dermis and epidermis of post-burn hypertrophic scar tissues. Burns 1999, 25, 43-48. [CrossRef]

66. Pileri, D.; Accardo Palombo, A.; D’Amelio, L.; D’Arpa, N.; Amato, G.; Masellis, A.; Cataldo, V.; Mogavero, R.; Napoli, B.; Lombardo, C.; et al. Concentrations of cytokines il-6 and il-10 in plasma of burn patients: Their relationship to sepsis and outcome. Ann. Burns Fire Disast. 2008, 21, 182-185.

67. Diehl, S.; Rincon, M. The two faces of il-6 on th1/th2 differentiation. Mol. Immunol. 2002, 39, 531-536. [CrossRef]

68. Hager, S.; Foldenauer, A.C.; Rennekampff, H.O.; Deisz, R.; Kopp, R.; Tenenhaus, M.; Gernot, M.; Pallua, N. Interleukin-6 serum levels correlate with severity of burn injury but not with gender. J. Burn Care Res. 2018, 39, 379-386. [CrossRef] [PubMed]

69. Entezami, K.Z.; Mosavi, T. Determination of lymphocytes surface markers in patients with thermal burns and the influence of burn size on mononuclear cell subsets. Med. J. Islam Repub. Iran 2017, 31, 38. [CrossRef]

70. Rose, L.F.; Chan, R.K. The burn wound microenvironment. Adv. Wound Care 2016, 5, 106-118. [CrossRef]

71. Wilgus, T.A.; Wulff, B.C. The importance of mast cells in dermal scarring. Adv. Wound Care 2014, 3, 356-365. [CrossRef]

72. Komi, D.E.A.; Khomtchouk, K.; Santa Maria, P.L. A review of the contribution of mast cells in wound healing: Involved molecular and cellular mechanisms. Clin. Rev. Allergy Immunol. 2020, 58, 298-312. [CrossRef]

73. Au, S.R.; Au, K.; Saggers, G.C.; Karne, N.; Ehrlich, H.P. Rat mast cells communicate with fibroblasts via gap junction intercellular communications. J. Cell Biochem. 2007, 100, 1170-1177. [CrossRef] [PubMed]

74. Foley, T.T.; Saggers, G.C.; Moyer, K.E.; Ehrlich, H.P. Rat mast cells enhance fibroblast proliferation and fibroblast-populated collagen lattice contraction through gap junctional intercellular communications. Plast. Reconstr. Surg. 2011, 127, 1478-1486. [CrossRef] [PubMed]

75. Foley, T.T.; Ehrlich, H.P. Through gap junction communications, co-cultured mast cells and fibroblasts generate fibroblast activities allied with hypertrophic scarring. Plast. Reconstr. Surg. 2013, 131, 1036-1044. [CrossRef] [PubMed]

76. Chen, L.; Schrementi, M.E.; Ranzer, M.J.; Wilgus, T.A.; DiPietro, L.A. Blockade of mast cell activation reduces cutaneous scar formation. PLoS ONE 2014, 9, e85226. [CrossRef] [PubMed] 
77. Wilgus, T.A. Immune cells in the healing skin wound: Influential players at each stage of repair. Pharmacol. Res. 2008, 58, 112-116. [CrossRef] [PubMed]

78. Santos, F.X.; Arroyo, C.; Garcia, I.; Blasco, R.; Obispo, J.M.; Hamann, C.; Espejo, L. Role of mast cells in the pathogenesis of postburn inflammatory response: Reactive oxygen species as mast cell stimulators. Burns 2000, 26, 145-147. [CrossRef]

79. Parihar, A.; Parihar, M.S.; Milner, S.; Bhat, S. Oxidative stress and anti-oxidative mobilization in burn injury. Burns 2008, 34, 6-17. [CrossRef]

80. Sirbulescu, R.F.; Boehm, C.K.; Soon, E.; Wilks, M.Q.; Ilies, I.; Yuan, H.; Maxner, B.; Chronos, N.; Kaittanis, C.; Normandin, M.D.; et al. Mature b cells accelerate wound healing after acute and chronic diabetic skin lesions. Wound Repair. Regen. 2017, 25, 774-791. [CrossRef]

81. Iwata, Y.; Yoshizaki, A.; Komura, K.; Shimizu, K.; Ogawa, F.; Hara, T.; Muroi, E.; Bae, S.; Takenaka, M.; Yukami, T.; et al. Cd19, a response regulator of $\mathrm{b}$ lymphocytes, regulates wound healing through hyaluronan-induced tlr4 signaling. Am. J. Pathol. 2009, 175, 649-660. [CrossRef]

82. Vinish, M.; Cui, W.; Stafford, E.; Bae, L.; Hawkins, H.; Cox, R.; Toliver-Kinsky, T. Dendritic cells modulate burn wound healing by enhancing early proliferation. Wound Repair. Regen. 2016, 24, 6-13. [CrossRef]

83. Gomes, I.; Mathur, S.K.; Espenshade, B.M.; Mori, Y.; Varga, J.; Ackerman, S.J. Eosinophil-fibroblast interactions induce fibroblast il-6 secretion and extracellular matrix gene expression: Implications in fibrogenesis. J. Allergy Clin. Immunol. 2005, 116, 796-804. [CrossRef] [PubMed]

84. Childs, D.R.; Murthy, A.S. Overview of wound healing and management. Surg. Clin. North. Am. 2017, 97, 189-207. [CrossRef] [PubMed]

85. Lenselink, E.A. Role of fibronectin in normal wound healing. Int. Wound J. 2015, 12, 313-316. [CrossRef] [PubMed]

86. Ehrlich, H.P.; Krummel, T.M. Regulation of wound healing from a connective tissue perspective. Wound Repair. Regen. 1996, 4 , 203-210. [CrossRef] [PubMed]

87. Li, B.; Wang, J.H. Fibroblasts and myofibroblasts in wound healing: Force generation and measurement. J. Tissue Viabil. 2011, 20, 108-120. [CrossRef] [PubMed]

88. Pastar, I.; Stojadinovic, O.; Yin, N.C.; Ramirez, H.; Nusbaum, A.G.; Sawaya, A.; Patel, S.B.; Khalid, L.; Isseroff, R.R.; Tomic-Canic, M. Epithelialization in wound healing: A comprehensive review. Adv. Wound Care 2014, 3, 445-464. [CrossRef]

89. Fuchs, E.; Raghavan, S. Getting under the skin of epidermal morphogenesis. Nat. Rev. Genet. 2002, 3, 199-209. [CrossRef]

90. Rousselle, P.; Braye, F.; Dayan, G. Re-epithelialization of adult skin wounds: Cellular mechanisms and therapeutic strategies. Adv. Drug Deliv. Rev. 2019, 146, 344-365. [CrossRef]

91. Lavker, R.M.; Sun, T.T. Epidermal stem cells: Properties, markers, and location. Proc. Natl. Acad. Sci. USA 2000, 97, 13473-13475. [CrossRef]

92. Watt, S.M.; Pleat, J.M. Stem cells, niches and scaffolds: Applications to burns and wound care. Adv. Drug Deliv. Rev. 2018, 123, 82-106. [CrossRef]

93. Zhang, X.; Yin, M.; Zhang, L.J. Keratin 6, 16 and 17-critical barrier alarmin molecules in skin wounds and psoriasis. Cells 2019, 8, 807. [CrossRef] [PubMed]

94. Rigal, C.; Pieraggi, M.T.; Vincent, C.; Prost, C.; Bouisou, H.; Serre, G. Healing of full-thickness cutaneous wounds in the pig. I. Immunohistochemical study of epidermo-dermal junction regeneration. J. Investig. Dermatol. 1991, 96, 777-785. [CrossRef] [PubMed]

95. Darby, I.A.; Laverdet, B.; Bonte, F.; Desmouliere, A. Fibroblasts and myofibroblasts in wound healing. Clin. Cosmet. Investig. Dermatol. 2014, 7, 301-311. [PubMed]

96. Kalluri, R.; Weinberg, R.A. The basics of epithelial-mesenchymal transition. J. Clin. Investig. 2009, 119, 1420-1428. [CrossRef] [PubMed]

97. Zeisberg, M.; Neilson, E.G. Biomarkers for epithelial-mesenchymal transitions. J. Clin. Investig. 2009, 119, 1429-1437. [CrossRef]

98. Taylor, M.A.; Parvani, J.G.; Schiemann, W.P. The pathophysiology of epithelial-mesenchymal transition induced by transforming growth factor-beta in normal and malignant mammary epithelial cells. J. Mamm. Gland Biol. Neoplas. 2010, 15, 169-190. [CrossRef]

99. Bolos, V.; Peinado, H.; Perez-Moreno, M.A.; Fraga, M.F.; Esteller, M.; Cano, A. The transcription factor slug represses e-cadherin expression and induces epithelial to mesenchymal transitions: A comparison with snail and e47 repressors. J. Cell Sci. 2003, 116, 499-511. [CrossRef]

100. Yang, J.; Mani, S.A.; Donaher, J.L.; Ramaswamy, S.; Itzykson, R.A.; Come, C.; Savagner, P.; Gitelman, I.; Richardson, A.; Weinberg, R.A. Twist, a master regulator of morphogenesis, plays an essential role in tumor metastasis. Cell 2004, 117, 927-939. [CrossRef]

101. Xiong, M.; Jiang, L.; Zhou, Y.; Qiu, W.; Fang, L.; Tan, R.; Wen, P.; Yang, J. The mir-200 family regulates tgf-beta1-induced renal tubular epithelial to mesenchymal transition through smad pathway by targeting zeb1 and zeb2 expression. Am. J. Physiol. Renal Physiol. 2012, 302, F369-F379. [CrossRef]

102. Radisky, D.C.; Kenny, P.A.; Bissell, M.J. Fibrosis and cancer: Do myofibroblasts come also from epithelial cells via emt? J. Cell. Biochem. 2007, 101, 830-839. [CrossRef]

103. Yan, C.; Grimm, W.A.; Garner, W.L.; Qin, L.; Travis, T.; Tan, N.; Han, Y.P. Epithelial to mesenchymal transition in human skin wound healing is induced by tumor necrosis factor-alpha through bone morphogenic protein-2. Am. J. Pathol. 2010, 176, 2247-2258. [CrossRef] [PubMed] 
104. Safferling, K.; Sutterlin, T.; Westphal, K.; Ernst, C.; Breuhahn, K.; James, M.; Jager, D.; Halama, N.; Grabe, N. Wound healing revised: A novel reepithelialization mechanism revealed by in vitro and in silico models. J. Cell. Biol. 2013, 203, 691-709. [CrossRef] [PubMed]

105. Aragona, M.; Dekoninck, S.; Rulands, S.; Lenglez, S.; Mascre, G.; Simons, B.D.; Blanpain, C. Defining stem cell dynamics and migration during wound healing in mouse skin epidermis. Nat. Commun. 2017, 8, 14684. [CrossRef] [PubMed]

106. Du, H.; Wang, Y.; Haensel, D.; Lee, B.; Dai, X.; Nie, Q. Multiscale modeling of layer formation in epidermis. PLoS Comput. Biol. 2018, 14, e1006006. [CrossRef] [PubMed]

107. Gal, P.; Varinska, L.; Faber, L.; Novak, S.; Szabo, P.; Mitrengova, P.; Mirossay, A.; Mucaji, P.; Smetana, K. How signaling molecules regulate tumor microenvironment: Parallels to wound repair. Molecules 2017, 22, 1818. [CrossRef]

108. Ji, S.Z.; Xiao, S.C.; Luo, P.F.; Huang, G.F.; Wang, G.Y.; Zhu, S.H.; Wu, M.J.; Xia, Z.F. An epidermal stem cells niche microenvironment created by engineered human amniotic membrane. Biomaterials 2011, 32, 7801-7811. [CrossRef]

109. Freedberg, I.M.; Tomic-Canic, M.; Komine, M.; Blumenberg, M. Keratins and the keratinocyte activation cycle. J. Invest. Dermatol. 2001, 116, 633-640. [CrossRef]

110. Li, J.; Chen, J.; Kirsner, R. Pathophysiology of acute wound healing. Clin. Dermatol. 2007, 25, 9-18. [CrossRef]

111. Fisher, G.; Rittie, L. Restoration of the basement membrane after wounding: A hallmark of young human skin altered with aging. J. Cell Commun Signal. 2018, 12, 401-411. [CrossRef]

112. Forte, E.; Chimenti, I.; Rosa, P.; Angelini, F.; Pagano, F.; Calogero, A.; Giacomello, A.; Messina, E. Emt/met at the crossroad of stemness, regeneration and oncogenesis: The ying-yang equilibrium recapitulated in cell spheroids. Cancers 2017, 9, 98. [CrossRef]

113. Thiery, J.P.; Acloque, H.; Huang, R.Y.; Nieto, M.A. Epithelial-mesenchymal transitions in development and disease. Cell 2009, 139, 871-890. [CrossRef] [PubMed]

114. Du, B.; Shim, J.S. Targeting epithelial-mesenchymal transition (emt) to overcome drug resistance in cancer. Molecules 2016, $21,965$. [CrossRef] [PubMed]

115. Ramesh, V.; Brabletz, T.; Ceppi, P. Targeting emt in cancer with repurposed metabolic inhibitors. Trends Cancer 2020, 6, 942-950. [CrossRef]

116. Pattabiraman, D.R.; Bierie, B.; Kober, K.I.; Thiru, P.; Krall, J.A.; Zill, C.; Reinhardt, F.; Tam, W.L.; Weinberg, R.A. Activation of pka leads to mesenchymal-to-epithelial transition and loss of tumor-initiating ability. Science 2016, 351, aad3680. [CrossRef] [PubMed]

117. Chen, A.F.; Liu, A.J.; Krishnakumar, R.; Freimer, J.W.; DeVeale, B.; Blelloch, R. Grhl2-dependent enhancer switching maintains a pluripotent stem cell transcriptional subnetwork after exit from naive pluripotency. Cell Stem Cell 2018, 23, 226-238 e224. [CrossRef] [PubMed]

118. Roca, H.; Hernandez, J.; Weidner, S.; McEachin, R.C.; Fuller, D.; Sud, S.; Schumann, T.; Wilkinson, J.E.; Zaslavsky, A.; Li, H.; et al. Transcription factors ovol1 and ovol2 induce the mesenchymal to epithelial transition in human cancer. PLoS ONE 2013, 8, e76773. [CrossRef] [PubMed]

119. Watanabe, K.; Villarreal-Ponce, A.; Sun, P.; Salmans, M.L.; Fallahi, M.; Andersen, B.; Dai, X. Mammary morphogenesis and regeneration require the inhibition of emt at terminal end buds by ovol2 transcriptional repressor. Dev. Cell 2014, 29, 59-74. [CrossRef] [PubMed]

120. Takaku, M.; Grimm, S.A.; Shimbo, T.; Perera, L.; Menafra, R.; Stunnenberg, H.G.; Archer, T.K.; Machida, S.; Kurumizaka, H.; Wade, P.A. Gata3-dependent cellular reprogramming requires activation-domain dependent recruitment of a chromatin remodeler. Genome Biol. 2016, 17, 36. [CrossRef]

121. Jagle, S.; Busch, H.; Freihen, V.; Beyes, S.; Schrempp, M.; Boerries, M.; Hecht, A. Snail1-mediated downregulation of foxa proteins facilitates the inactivation of transcriptional enhancer elements at key epithelial genes in colorectal cancer cells. PLoS Genet. 2017, 13, e1007109. [CrossRef]

122. Chen, J.; Liu, J.; Yang, J.; Chen, Y.; Chen, J.; Ni, S.; Song, H.; Zeng, L.; Ding, K.; Pei, D. Bmps functionally replace klf4 and support efficient reprogramming of mouse fibroblasts by oct4 alone. Cell Res. 2011, 21, 205-212. [CrossRef]

123. Hu, X.; Zhang, L.; Mao, S.Q.; Li, Z.; Chen, J.; Zhang, R.R.; Wu, H.P.; Gao, J.; Guo, F.; Liu, W.; et al. Tet and tdg mediate DNA demethylation essential for mesenchymal-to-epithelial transition in somatic cell reprogramming. Cell Stem Cell 2014, 14, 512-522. [CrossRef] [PubMed]

124. Sakurai, K.; Talukdar, I.; Patil, V.S.; Dang, J.; Li, Z.; Chang, K.Y.; Lu, C.C.; Delorme-Walker, V.; Dermardirossian, C.; Anderson, K.; et al. Kinome-wide functional analysis highlights the role of cytoskeletal remodeling in somatic cell reprogramming. Cell Stem Cell 2014, 14, 523-534. [CrossRef] [PubMed]

125. Brabletz, S.; Brabletz, T. The zeb/mir-200 feedback loop-A motor of cellular plasticity in development and cancer? EMBO Rep. 2010, 11, 670-677. [CrossRef] [PubMed]

126. Watanabe, K.; Liu, Y.; Noguchi, S.; Murray, M.; Chang, J.C.; Kishima, M.; Nishimura, H.; Hashimoto, K.; Minoda, A.; Suzuki, H. Ovol2 induces mesenchymal-to-epithelial transition in fibroblasts and enhances cell-state reprogramming towards epithelial lineages. Sci. Rep. 2019, 9, 6490. [CrossRef] [PubMed]

127. Sahai, E.; Astsaturov, I.; Cukierman, E.; DeNardo, D.G.; Egeblad, M.; Evans, R.M.; Fearon, D.; Greten, F.R.; Hingorani, S.R.; Hunter, T.; et al. A framework for advancing our understanding of cancer-associated fibroblasts. Nat. Rev. Cancer 2020, 20, 174-186. [CrossRef]

128. Erez, N.; Truitt, M.; Olson, P.; Arron, S.T.; Hanahan, D. Cancer-associated fibroblasts are activated in incipient neoplasia to orchestrate tumor-promoting inflammation in an nf-kappab-dependent manner. Cancer Cell 2010, 17, 135-147. [CrossRef] 
129. desJardins-Park, H.E.; Chinta, M.S.; Foster, D.S.; Borrelli, M.R.; Shen, A.H.; Wan, D.C.; Longaker, M.T. Fibroblast heterogeneity in and its implications for plastic and reconstructive surgery: A basic science review. Plast. Reconstr. Surg. Glob. Open 2020, 8, e2927.

130. Vorstandlechner, V.; Laggner, M.; Kalinina, P.; Haslik, W.; Radtke, C.; Shaw, L.; Lichtenberger, B.M.; Tschachler, E.; Ankersmit, H.J.; Mildner, M. Deciphering the functional heterogeneity of skin fibroblasts using single-cell rna sequencing. FASEB J. 2020, 34, 3677-3692. [CrossRef]

131. Jiang, D.; Rinkevich, Y. Scars or regeneration?-dermal fibroblasts as drivers of diverse skin wound responses. Int. J. Mol. Sci 2020, 21, 617. [CrossRef]

132. Reilkoff, R.A.; Bucala, R.; Herzog, E.L. Fibrocytes: Emerging effector cells in chronic inflammation. Nat. Rev. Immunol. 2011, 11, 427-435. [CrossRef]

133. Gabbiani, G. The myofibroblast in wound healing and fibrocontractive diseases. J. Pathol. 2003, 200, 500-503. [CrossRef] [PubMed]

134. Li, H.; Yao, Z.; He, W.; Gao, H.; Bai, Y.; Yang, S.; Zhang, L.; Zhan, R.; Tan, J.; Zhou, J.; et al. P311 induces the transdifferentiation of epidermal stem cells to myofibroblast-like cells by stimulating transforming growth factor beta1 expression. Stem Cell Res. Ther. 2016, 7, 175. [CrossRef] [PubMed]

135. Saikia, P.; Crabb, J.S.; Dibbin, L.L.; Juszczak, M.J.; Willard, B.; Jang, G.F.; Shiju, T.M.; Crabb, J.W.; Wilson, S.E. Quantitative proteomic comparison of myofibroblasts derived from bone marrow and cornea. Sci Rep. 2020, 10, 16717. [CrossRef]

136. Piera-Velazquez, S.; Li, Z.; Jimenez, S.A. Role of endothelial-mesenchymal transition (endomt) in the pathogenesis of fibrotic disorders. Am. J. Pathol. 2011, 179, 1074-1080. [CrossRef] [PubMed]

137. Kirkpatrick, L.D.; Shupp, J.W.; Smith, R.D.; Alkhalil, A.; Moffatt, L.T.; Carney, B.C. Galectin-1 production is elevated in hypertrophic scar. Wound Repair. Regen. 2020. [CrossRef] [PubMed]

138. Lin, Y.T.; Chen, J.S.; Wu, M.H.; Hsieh, I.S.; Liang, C.H.; Hsu, C.L.; Hong, T.M.; Chen, Y.L. Galectin-1 accelerates wound healing by regulating the neuropilin-1/smad3/nox4 pathway and ros production in myofibroblasts. J. Investig. Dermatol. 2015, 135, 258-268. [CrossRef] [PubMed]

139. Grotendorst, G.R.; Duncan, M.R. Individual domains of connective tissue growth factor regulate fibroblast proliferation and myofibroblast differentiation. FASEB J. 2005, 19, 729-738. [CrossRef] [PubMed]

140. Desmouliere, A.; Geinoz, A.; Gabbiani, F.; Gabbiani, G. Transforming growth factor-beta 1 induces alpha-smooth muscle actin expression in granulation tissue myofibroblasts and in quiescent and growing cultured fibroblasts. J. Cell Biol. 1993, 122, $103-111$. [CrossRef]

141. Glim, J.E.; Niessen, F.B.; Everts, V.; van Egmond, M.; Beelen, R.H. Platelet derived growth factor-cc secreted by $\mathrm{m} 2 \mathrm{macrophages}$ induces alpha-smooth muscle actin expression by dermal and gingival fibroblasts. Immunobiology 2013, 218, 924-929. [CrossRef]

142. Lian, N.; Li, T. Growth factor pathways in hypertrophic scars: Molecular pathogenesis and therapeutic implications. Biomed. Pharmacother. 2016, 84, 42-50. [CrossRef]

143. Limandjaja, G.C.; Niessen, F.B.; Scheper, R.J.; Gibbs, S. Hypertrophic scars and keloids: Overview of the evidence and practical guide for differentiating between these abnormal scars. Exp. Dermatol. 2020, 30, 146-161. [CrossRef] [PubMed]

144. Ghazawi, F.M.; Zargham, R.; Gilardino, M.S.; Sasseville, D.; Jafarian, F. Insights into the pathophysiology of hypertrophic scars and keloids: How do they differ? Adv. Skin Wound Care 2018, 31, 582-595. [CrossRef] [PubMed]

145. Honnegowda, T.; Kumar, P.; Udupa, E.; Kumar, S.; Kumar, U.; Rao, P. Role of angiogenesis and angiogenic factors in acute and chronic wound healing. Plast. Aesthet. Res. 2015, 2, 243.

146. Breier, G.; Blum, S.; Peli, J.; Groot, M.; Wild, C.; Risau, W.; Reichmann, E. Transforming growth factor-beta and ras regulate the vegf/vegf-receptor system during tumor angiogenesis. Int. J. Cancer 2002, 97, 142-148. [CrossRef] [PubMed]

147. Nagy, J.A.; Benjamin, L.; Zeng, H.; Dvorak, A.M.; Dvorak, H.F. Vascular permeability, vascular hyperpermeability and angiogenesis. Angiogenesis 2008, 11, 109-119. [CrossRef]

148. Dvorak, H.F.; Nagy, J.A.; Feng, D.; Brown, L.F.; Dvorak, A.M. Vascular permeability factor/vascular endothelial growth factor and the significance of microvascular hyperpermeability in angiogenesis. Curr. Top. Microbiol. Immunol. 1999, $237,97-132$.

149. Ornitz, D.M.; Itoh, N. Fibroblast growth factors. Genome Biol. 2001, 2, 3005. [CrossRef]

150. Majima, M.; Hayashi, I.; Muramatsu, M.; Katada, J.; Yamashina, S.; Katori, M. Cyclo-oxygenase-2 enhances basic fibroblast growth factor-induced angiogenesis through induction of vascular endothelial growth factor in rat sponge implants. Br. J. Pharmacol. 2000, 130, 641-649. [CrossRef]

151. Pintucci, G.; Froum, S.; Pinnell, J.; Mignatti, P.; Rafii, S.; Green, D. Trophic effects of platelets on cultured endothelial cells are mediated by platelet-associated fibroblast growth factor-2 (fgf-2) and vascular endothelial growth factor (vegf). Thromb. Haemost. 2002, 88, 834-842. [CrossRef]

152. Nath, S.G.; Raveendran, R. An insight into the possibilities of fibroblast growth factor in periodontal regeneration. J. Ind. Soc. Periodontol. 2014, 18, 289-292. [CrossRef]

153. Yoshida, S.; Yoshida, A.; Matsui, H.; Takada, Y.; Ishibashi, T. Involvement of macrophage chemotactic protein-1 and interleukin1 beta during inflammatory but not basic fibroblast growth factor-dependent neovascularization in the mouse cornea. Lab. Invest. J. Tech. Methods Pathol. 2003, 83, 927-938. [CrossRef] [PubMed]

154. Barrientos, S.; Stojadinovic, O.; Golinko, M.S.; Brem, H.; Tomic-Canic, M. Growth factors and cytokines in wound healing. Wound Repair Regen. 2008, 16, 585-601. [CrossRef] [PubMed]

155. Mans, S.; Banz, Y.; Mueller, B.U.; Pabst, T. The angiogenesis inhibitor vasostatin is regulated by neutrophil elastase-dependent cleavage of calreticulin in aml patients. Blood 2012, 120, 2690-2699. [CrossRef] [PubMed] 
156. Inoki, I.; Shiomi, T.; Hashimoto, G.; Enomoto, H.; Nakamura, H.; Makino, K.; Ikeda, E.; Takata, S.; Kobayashi, K.; Okada, Y. Connective tissue growth factor binds vascular endothelial growth factor (vegf) and inhibits vegf-induced angiogenesis. FASEB J. 2002, 16, 219-221. [CrossRef] [PubMed]

157. Grimm, D.; Bauer, J.; Schoenberger, J. Blockade of neoangiogenesis, a new and promising technique to control the growth of malignant tumors and their metastases. Curr. Vasc. Pharmacol. 2009, 7, 347-357. [CrossRef]

158. Bootle-Wilbraham, C.A.; Tazzyman, S.; Thompson, W.D.; Stirk, C.M.; Lewis, C.E. Fibrin fragment e stimulates the proliferation, migration and differentiation of human microvascular endothelial cells in vitro. Angiogenesis 2001, 4, 269-275. [CrossRef]

159. Zhang, X.; Liu, L.; Wei, X.; Tan, Y.S.; Tong, L.; Chang, R.; Ghanamah, M.S.; Reinblatt, M.; Marti, G.P.; Harmon, J.W.; et al. Impaired angiogenesis and mobilization of circulating angiogenic cells in hif-1alpha heterozygous-null mice after burn wounding. Wound Repair Regen. 2010, 18, 193-201. [CrossRef]

160. Fox, A.; Smythe, J.; Fisher, N.; Tyler, M.P.; McGrouther, D.A.; Watt, S.M.; Harris, A.L. Mobilization of endothelial progenitor cells into the circulation in burned patients. Br. J. Surg. 2008, 95, 244-251. [CrossRef]

161. Foresta, C.; Schipilliti, M.; De Toni, L.; Magagna, S.; Lancerotto, L.; Azzena, B.; Vindigni, V.; Mazzoleni, F. Blood levels, apoptosis, and homing of the endothelial progenitor cells after skin burns and escharectomy. J. Trauma 2011, 70, 459-465. [CrossRef]

162. Bates, D.O.; Heald, R.I.; Curry, F.E.; Williams, B. Vascular endothelial growth factor increases rana vascular permeability and compliance by different signalling pathways. J. Physiol. 2001, 533, 263-272. [CrossRef]

163. Zittermann, S.I.; Issekutz, A.C. Endothelial growth factors vegf and bfgf differentially enhance monocyte and neutrophil recruitment to inflammation. J. Leukoc. Biol. 2006, 80, 247-257. [CrossRef] [PubMed]

164. Detmar, M.; Brown, L.F.; Schon, M.P.; Elicker, B.M.; Velasco, P.; Richard, L.; Fukumura, D.; Monsky, W.; Claffey, K.P.; Jain, R.K. Increased microvascular density and enhanced leukocyte rolling and adhesion in the skin of vegf transgenic mice. J. Investig. Dermatol. 1998, 111, 1-6. [CrossRef] [PubMed]

165. Wulff, B.C.; Parent, A.E.; Meleski, M.A.; DiPietro, L.A.; Schrementi, M.E.; Wilgus, T.A. Mast cells contribute to scar formation during fetal wound healing. J. Investig. Dermatol. 2012, 132, 458-465. [CrossRef]

166. Reinders, M.E.; Sho, M.; Izawa, A.; Wang, P.; Mukhopadhyay, D.; Koss, K.E.; Geehan, C.S.; Luster, A.D.; Sayegh, M.H.; Briscoe, D.M. Proinflammatory functions of vascular endothelial growth factor in alloimmunity. J. Clin. Investig. 2003, 112, 1655-1665. [CrossRef] [PubMed]

167. Bagabir, R.; Byers, R.J.; Chaudhry, I.H.; Muller, W.; Paus, R.; Bayat, A. Site-specific immunophenotyping of keloid disease demonstrates immune upregulation and the presence of lymphoid aggregates. Br. J. Dermatol. 2012, 167, 1053-1066. [CrossRef] [PubMed]

168. Barleon, B.; Sozzani, S.; Zhou, D.; Weich, H.A.; Mantovani, A.; Marme, D. Migration of human monocytes in response to vascular endothelial growth factor (vegf) is mediated via the vegf receptor flt-1. Blood 1996, 87, 3336-3343. [CrossRef] [PubMed]

169. Stockmann, C.; Kirmse, S.; Helfrich, I.; Weidemann, A.; Takeda, N.; Doedens, A.; Johnson, R.S. A wound size-dependent effect of myeloid cell-derived vascular endothelial growth factor on wound healing. J. Investig. Dermatol. 2011, 131, 797-801. [CrossRef]

170. Jacobi, J.; Tam, B.Y.; Sundram, U.; von Degenfeld, G.; Blau, H.M.; Kuo, C.J.; Cooke, J.P. Discordant effects of a soluble vegf receptor on wound healing and angiogenesis. Gene Ther. 2004, 11, 302-309. [CrossRef] [PubMed]

171. Frank, S.; Hubner, G.; Breier, G.; Longaker, M.T.; Greenhalgh, D.G.; Werner, S. Regulation of vascular endothelial growth factor expression in cultured keratinocytes. Implications for normal and impaired wound healing. J. Biol. Chem. 1995, 270, 12607-12613. [CrossRef]

172. Wilgus, T.A.; Ferreira, A.M.; Oberyszyn, T.M.; Bergdall, V.K.; Dipietro, L.A. Regulation of scar formation by vascular endothelial growth factor. Lab. Invest. J. Tech. Methods Pathol. 2008, 88, 579-590. [CrossRef]

173. Cao, P.F.; Xu, Y.B.; Tang, J.M.; Yang, R.H.; Liu, X.S. Hoxa9 regulates angiogenesis in human hypertrophic scars: Induction of vegf secretion by epidermal stem cells. Int. J. Clin. Exp. Pathol. 2014, 7, 2998-3007. [PubMed]

174. Wang, J.; Chen, H.; Shankowsky, H.A.; Scott, P.G.; Tredget, E.E. Improved scar in postburn patients following interferon-alpha2b treatment is associated with decreased angiogenesis mediated by vascular endothelial cell growth factor. J. Interf. Cytok. Res. 2008, 28, 423-434. [CrossRef] [PubMed]

175. Mejia, I.; Bodapati, S.; Chen, K.T.; Diaz, B. Pancreatic adenocarcinoma invasiveness and the tumor microenvironment: From biology to clinical trials. Biomedicines 2020, 8, 401. [CrossRef] [PubMed]

176. Jobe, N.P.; Zivicova, V.; Mifkova, A.; Rosel, D.; Dvorankova, B.; Kodet, O.; Strnad, H.; Kolar, M.; Sedo, A.; Smetana, K., Jr.; et al. Fibroblasts potentiate melanoma cells in vitro invasiveness induced by uv-irradiated keratinocytes. Histochem. Cell Biol. 2018, 149, 503-516. [CrossRef] [PubMed]

177. Boyuk, E.; Saracoglu, Z.N.; Arik, D. Cutaneous leiomyoma mimicking a keloid. Acta Dermatovenerol. Croat. $2020,28,116$.

178. Zhou, B.Y.; Wang, W.B.; Wu, X.L.; Zhang, W.J.; Zhou, G.D.; Gao, Z.; Liu, W. Nintedanib inhibits keloid fibroblast functions by blocking the phosphorylation of multiple kinases and enhancing receptor internalization. Acta Pharmacol. Sin. 2020, 41, 1234-1245. [CrossRef]

179. Schulz, J.N.; Plomann, M.; Sengle, G.; Gullberg, D.; Krieg, T.; Eckes, B. New developments on skin fibrosis—Essential signals emanating from the extracellular matrix for the control of myofibroblasts. Matrix Biol. 2018, 68, 522-532. [CrossRef]

180. Barnes, L.A.; Marshall, C.D.; Leavitt, T.; Hu, M.S.; Moore, A.L.; Gonzalez, J.G.; Longaker, M.T.; Gurtner, G.C. Mechanical forces in cutaneous wound healing: Emerging therapies to minimize scar formation. Adv. Wound Care 2018, 7, 47-56. [CrossRef] 
181. Shah, M.; Foreman, D.M.; Ferguson, M.W. Neutralisation of tgf-beta 1 and tgf-beta 2 or exogenous addition of tgf-beta 3 to cutaneous rat wounds reduces scarring. J. Cell Sci. 1995, 108, 985-1002.

182. Theocharis, A.D.; Manou, D.; Karamanos, N.K. The extracellular matrix as a multitasking player in disease. FEBS J. 2019, 286, 2830-2869. [CrossRef]

183. Januszyk, M.; Kwon, S.H.; Wong, V.W.; Padmanabhan, J.; Maan, Z.N.; Whittam, A.J.; Major, M.R.; Gurtner, G.C. The role of focal adhesion kinase in keratinocyte fibrogenic gene expression. Int. J. Mol. Sci. 2017, 18, 1915. [CrossRef] [PubMed]

184. Dvorak, H.F. Tumors: Wounds that do not heal. Similarities between tumor stroma generation and wound healing. N. Eng. J. Med. 1986, 315, 1650-1659.

185. Dvorak, H.F. Tumors: Wounds that do not heal-redux. Cancer Immunol. Res. 2015, 3, 1-11. [CrossRef] [PubMed]

186. Ladin, D.A.; Hou, Z.; Patel, D.; McPhail, M.; Olson, J.C.; Saed, G.M.; Fivenson, D.P. P53 and apoptosis alterations in keloids and keloid fibroblasts. Wound Repair Regen. 1998, 6, 28-37. [CrossRef] [PubMed]

187. Hanahan, D.; Weinberg, R.A. Hallmarks of cancer: The next generation. Cell 2011, 144, 646-674. [CrossRef] [PubMed]

188. Tan, S.; Khumalo, N.; Bayat, A. Understanding keloid pathobiology from a quasi-neoplastic perspective: Less of a scar and more of a chronic inflammatory disease with cancer-like tendencies. Front. Immunol 2019, 10, 1810. [CrossRef]

189. Rees, P.A.; Greaves, N.S.; Baguneid, M.; Bayat, A. Chemokines in wound healing and as potential therapeutic targets for reducing cutaneous scarring. Adv. Wound Care 2015, 4, 687-703. [CrossRef]

190. Taylor, A.; Budd, D.C.; Shih, B.; Seifert, O.; Beaton, A.; Wright, T.; Dempsey, M.; Kelly, F.; Egerton, J.; Marshall, R.P.; et al. Transforming growth factor beta gene signatures are spatially enriched in keloid tissue biopsies and ex vivo-cultured keloid fibroblasts. Acta Derm. Venereol. 2017, 97, 10-16. [CrossRef] 